\title{
Clerodendrum volubile Ethanol Leaf Extract: A Potential Antidote to Doxorubicin-Induced Cardiotoxicity in Rats
}

\author{
Olufunke Esan Olorundare, ${ }^{1}$ Adejuwon Adewale Adeneye ${ }^{(D)},{ }^{2}$ Akinyele Olubiyi Akinsola, ${ }^{1}$ \\ Daniel Ayodele Sanni, ${ }^{3}$ Mamoru Koketsu $\left(\mathbb{0},{ }^{4}\right.$ and Hasan Mukhtar ${ }^{5}$ \\ ${ }^{1}$ Department of Pharmacology and Therapeutics, Faculty of Basic Medical Sciences, College of Health Sciences, \\ University of Ilorin, Ilorin, Kwara, Nigeria \\ ${ }^{2}$ Department of Pharmacology, Therapeutics and Toxicology, Faculty of Basic Clinical Sciences, \\ Lagos State University College of Medicine, 1-5 Oba Akinjobi Way, G.R.A., Ikeja, Lagos, Nigeria \\ ${ }^{3}$ Department of Pathology and Forensic Medicine, Faculty of Basic Clinical Sciences, Lagos State University College of Medicine, \\ 1-5 Oba Akinjobi Way, G.R.A., Ikeja, Lagos, Nigeria \\ ${ }^{4}$ Department of Chemistry and Biomolecular Science, Faculty of Engineering, Gifu University, 1-1 Yanagido, \\ Gifu 501-1193, Japan \\ ${ }^{5}$ Department of Dermatology, University of Wisconsin-Madison, Medical Science Center, 1300 University Avenue, Madison, \\ WI 53706, USA
}

Correspondence should be addressed to Adejuwon Adewale Adeneye; adeneye2001@yahoo.com

Received 5 March 2020; Accepted 11 June 2020; Published 4 July 2020

Academic Editor: You-Cheng Hseu

Copyright (๑) 2020 Olufunke Esan Olorundare et al. This is an open access article distributed under the Creative Commons Attribution License, which permits unrestricted use, distribution, and reproduction in any medium, provided the original work is properly cited.

\begin{abstract}
Doxorubicin is widely applied in hematological and solid tumor treatment but limited by its off-target cardiotoxicity. Thus, cardioprotective potential and mechanism(s) of CVE in DOX-induced cardiotoxicity were investigated using cardiac and oxidative stress markers and histopathological endpoints. $50-400 \mathrm{mg} / \mathrm{kg} /$ day $C V E$ in $5 \%$ DMSO in distilled water were investigated in Wistar rats intraperitoneally injected with $2.5 \mathrm{mg} / \mathrm{kg}$ DOX on alternate days for 14 days, using serum troponin I and LDH, complete lipid profile, cardiac tissue oxidative stress marker assays, and histopathological examination of DOX-treated cardiac tissue. Preliminary qualitative and quantitative assays of CVE's secondary metabolites were also conducted. Phytochemical analyses revealed the presence of flavonoids $(34.79 \pm 0.37 \mathrm{mg} / 100 \mathrm{mg}$ dry extract), alkaloids $(36.73 \pm 0.27 \mathrm{mg} / 100 \mathrm{mg}$ dry extract), reducing sugars $(07.78 \pm 0.09 \mathrm{mg} / 100 \mathrm{mg}$ dry extract), and cardiac glycosides $(24.55 \pm 0.12 \mathrm{mg} / 100 \mathrm{mg}$ dry extract). $50-400 \mathrm{mg} / \mathrm{kg} /$ day CVE significantly attenuated increases in the serum LDH and troponin I levels. Similarly, the CVE dose unrelatedly decreased serum TG and VLDL-c levels without significant alterations in the serum TC, HDL-c, and LDL-c levels. Also, CVE profoundly attenuated alterations in the cardiac tissue oxidative stress markers' activities while improving DOX-associated cardiac histological lesions that were possibly mediated via free radical scavenging and/or antioxidant mechanisms. Overall, CVE may play a significant therapeutic role in the management of DOX-induced cardiotoxicity in humans.
\end{abstract}

\section{Introduction}

Drug-induced cardiotoxicity remains the most widely studied of drug-induced organ toxicities [1]. Several approved drugs and agrochemicals have been implicated in these toxicities, including acetaminophen, gentamicin, rifampicin, carbon tetrachloride, and antineoplastic drugs [2].
Thus, accidental, acute overdose, or chronic use of some of these drugs could result in multiorgan toxicities including hepatotoxicity, nephrotoxicity, cardiotoxicity, and testicular/ovarian toxicity. These specific organs are known to be mostly susceptible and are organs of metabolism and excretion of these drugs [3]. Despite extensive studies of these organ toxicities, definitive therapeutic/prophylactic options 
at ameliorating the deleterious effects of these drugs are still limited. In view of this, research into the etiopathology and development of alternative or complementary options from traditional medicine is currently been encouraged [4]. Also, the World Health Organization reported that over $80 \%$ of the world population depends partly or wholly on medicinal plant-derived pharmaceuticals [5].

Doxorubicin (DOX) is a broad-spectrum antibiotic anthracycline with wide application in the clinical chemotherapeutic management of solid tumors such as breast, lung, ovarian, and uterine cancers and leukemias [6]. Despite its incontrovertible efficacy, DOX is notorious for its life-threatening toxicity profile such as neurotoxicity, hepatotoxicity, hematotoxicity, and cardiotoxicity, thus limiting its clinical use in cancer treatment. Life-threatening cardiomyopathy represents the cumulative doselimiting toxicity of the drug. DOX toxicities are majorly attributed to the interplay of oxidative stress and free radical formation from its highly reactive and toxic secondary metabolites [7].

In African traditional medicine, several medicinal plants are reputed for effectively ameliorating the deleterious effects of drug poisoning on organs such as the liver and the kidneys. These medicinal plants (in whole or parts) include Phyllanthus amarus, Harungana madagascariensis, Carica papaya leaves, Zingiber officinale rhizome, Vernonia amygdalina leaves, and Garcinia kola seeds [8, 9]. However, the folkloric therapeutic claims of some of these plants have been scientifically verified and reported. For example, the protective activities of various plant extracts of Phyllanthus amarus [10-12], Harungana madagascariensis [13], Carica papaya leaves [14, 15], Zingiber officinale rhizome [16-19], Vernonia amygdalina leaves [20,21], and Garcinia kola seeds $[22,23]$ against drug-induced hepato- and nephrotoxicities are well documented. Similarly, several studies have equally reported ameliorative effects of medicinal plants against drug-induced cardiotoxicity [24-28].

Clerodendrum volubile P. Beauv, popularly known as white butterfly, belongs to the Lamiaceae family. In Nigeria, the plant is locally known as "Marugbo" or "Eweta" among the Ikale, Ilaje, and Apoi people of Ondo State (Southwest Nigeria) and "Obnettete" among the Itsekiri and Urhobo tribes (Niger Delta area of Nigeria) where it is often combined with other vegetables as a condiment and spice to improve taste and aroma [29]. Clerodendrum volubile is indigenous and ubiquitous to the riverine belts of the West African tropical rainforest of Nigeria, Benin Republic, Ghana, Cameroon, Burkina Faso, and Sierra Leone where it is also grown as an ornamental plant $[30,31]$. Due to its high nutritive and ethnopharmacological value, Clerodendrum volubile whole plant and its parts are used in the African ethnomedicine in the local management of joint pains and swellings, diabetes mellitus, gastric ulcer, obesity and hyperlipidemia, hypertension, and other heart diseases and dropsy [31, 32]. However, some of these folkloric claims have been scientifically validated and have been attributed to its high polyphenol content such as ajugoside, pectolinarigenin, protocatechuic acid, biochanin, and 5, 7, 4'-trimethoxykaempferol [31]. Clerodendrum volubile has also been reported to exhibit potential role in the management of human breast cancer by inhibiting cell cycle phases, especially the $G_{0} / G_{1}$ phase, cell proliferation, and decreasing the expression of matrix metalloproteinase 9 enzymes [33], as well as the ability of its extracts to scavenge free radicals, especially reactive oxygen species, generated by human breast cancer cell lines in vitro [33] and its antiproliferative activity against prostate cancer cells [34]. Considering the wide application and historical use of different plant parts of Clerodendrum volubile in the traditional management of heart diseases, the reported role of reactive oxidative stress in the etiopathogenesis of doxorubicin-related heart disease, and paucity of scientific validation of the plant use in the management of drug-related heart diseases including druginduced cardiotoxicity, the present exploratory study is, therefore, designed at evaluating the possible antidotal potential of $100-400 \mathrm{mg} / \mathrm{kg}$ of the Clerodendrum volubile ethanol leaf extract (CVE) in doxorubicin- (DOX-) induced cardiotoxic rats for 14 days. In doing this, reliable cardiac injury biomarkers (serum troponin I and $\mathrm{LDH}$ ), indices of cardiovascular disease, as well as histopathological studies of CVE-DOX-treated cardiac muscles, were evaluated. In addition, the effect of CVE on SOD, CAT, GSH, GPx, GST, and MAD activities in the DOX-treated cardiac tissues was evaluated.

\section{Materials and Methods}

2.1. Plant Materials. Stock of fresh mature whole plants of Clerodendrum volubile was purchased from Herbal Vendors in the Isikan Market in Akure, Ondo State, Nigeria, in the month of March 2019. Samples of the plant obtained were subjected to botanical identification and referencing at the University of Ilorin (UNILORIN) Herbarium, with the voucher specimen number UILH/01/019/1254 allotted.

2.2. Extraction Process. Fresh leaves of Clerodendrum volubile were destalked from the whole plant and then gently but thoroughly rinsed under running tap water and completely air-dried at the room temperature $\left(28-33^{\circ} \mathrm{C}\right)$ until the weight of the dried leaves was constant. The dried leaves were then pulverized using the milling machine and kept in a water- and air-tight container.

$1.50 \mathrm{~kg}$ of the pulverized leaves was completely macerated in 8 liters of absolute ethanol at room temperature for 5 days but intermittently shaken to ensure complete dissolution. Thereafter, the solution was first filtered with cotton wool and then with the $110 \mathrm{~mm}$ Whatman filter paper. The resultant filtrate was then concentrated in vacuo using a rotary evaporator (BUCHI Rotavapor ${ }^{\circledR}$ Model R-215, Switzerland) with the Vacuum Module V-801 EasyVac ${ }^{\circledR}$, Switzerland) set at a revolution of $70 \mathrm{rpm}$ and a temperature at $36^{\circ} \mathrm{C}$ before it was completely dried over a waterbath preset at $40^{\circ} \mathrm{C}$. The jelly-like, dark-colored residue left behind was weighed and stored in an air- and water-proof container which was kept in a refrigerator at $4^{\circ} \mathrm{C}$. From this stock, fresh solutions were made whenever required. 
$\%$ yield $=\frac{\text { weight of the crude extract obtained }(\mathrm{g})}{\text { weight of the starting pulverized dry leaf extracted }(\mathrm{g})} \times 100$

2.3. Preliminary Qualitative Phytochemical Analysis. The presence of saponins, tannins, alkaloids, flavonoids, anthraquinones, glycosides, and reducing sugars was detected by the simple and standard qualitative and quantitative methods described by Trease and Evans [35] and Sofowora [36].

\subsection{Quantitative Determination of Secondary Metabolites in CVE}

2.4.1. Preparation of Fat-Free Sample. $2 \mathrm{~g}$ of CVE was exhaustively defatted with $100 \mathrm{ml}$ of diethyl ether using the method earlier described by Edeoga et al. [37].

2.4.2. Total Phenol Quantification. The total phenolic content in CVE was spectrophotometrically determined using the procedure previously described by Edeoga et al. [37].

2.4.3. Alkaloid Quantification. The alkaloid content of CVE was determined using the method earlier described by Harborne [38]. $5 \mathrm{~g}$ of CVE was weighed into a $250 \mathrm{ml}$ beaker, and $200 \mathrm{ml}$ of $10 \%$ acetic acid in ethanol was added. The resulting solution was covered and allowed to stand for 4 hours, filtered, and then the filtrate was concentrated on a waterbath to one-quarter of the original volume. Concentrated ammonium hydroxide was added drop-wise to the concentrate until the precipitation was complete. The whole solution was allowed to settle, and the precipitate was collected and rinsed with dilute ammonium hydroxide and then filtered. The residue is the alkaloid, which was dried and weighed.

2.4.4. Tannin Quantification. Tannin content of CVE was estimated using the method by Van-Burden and Robinson [39]. $500 \mathrm{mg}$ of defatted CVE was weighed into a $50 \mathrm{ml}$ plastic bottle. $50 \mathrm{ml}$ of distilled water was added and shaken continuously for 1 hour on a mechanical shaker. This was filtered into a $50 \mathrm{ml}$ volumetric flask and made up to the mark. Following this, $5 \mathrm{ml}$ of the filtrate was pipetted out into a test tube and mixed with $2 \mathrm{ml}$ of $0.1 \mathrm{M} \mathrm{FeCl}_{3}$ in $0.1 \mathrm{~N}$ $\mathrm{HCl}$ and $0.008 \mathrm{M}$ potassium ferrocyanide. The absorbance of the resulting mixture was measured at $120 \mathrm{~nm}$ within $10 \mathrm{~min}$.

2.4.5. Saponin Quantification. Saponin was estimated by the method previously used by Obadoni and Ochuko [40]. $2 \mathrm{~g}$ of $C V E$ was placed into a conical flask, and $10 \mathrm{ml}$ of $20 \%$ aqueous ethanol was added. The resulting mixture was heated over a hot waterbath for 4 hours under continuous stirring at $55^{\circ} \mathrm{C}$. The mixture was filtered, and the residue was re-extracted with another $20 \mathrm{ml}$ of $20 \%$ ethanol. The combined filtrate was reduced to $4 \mathrm{ml}$ over a waterbath at $90^{\circ} \mathrm{C}$. The concentrate was transferred into a $50 \mathrm{ml}$ separating funnel, and $2 \mathrm{ml}$ of diethyl ether was added and shaken vigorously. The aqueous layer was recovered, while the ether layer was discarded. The extraction process was repeated one more time, and n-butanol was added to the combined aqueous portion. The resulting mixture was shaken and washed twice with $1 \mathrm{ml}$ of $5 \%$ aqueous sodium chloride and filtered, while the resulting solution was heated over a waterbath. After evaporation, the samples were dried in the oven to a constant weight, and the saponin content was calculated as the percentage of the extract.

2.4.6. Reducing Sugar Quantification. Reducing sugar content in CVE was determined using the spectrophotometric method as described by Shaffer and Somogyi [41].

\subsubsection{Quantitative Determination of Total Flavonoid Content} in CVE. Total flavonoids in CVE were estimated using the method by Ordonez et al. [42]. To $1 \mathrm{ml}$ of crude CVE, equivalent $1 \mathrm{ml}$ of $2 \%$ aluminum chloride in the ethanol solution was added. After 1 hour of incubation at room temperature $\left(28^{\circ} \mathrm{C}\right)$ for color development, the absorbance was measured at $420 \mathrm{~nm}$ using the ${ }^{\circledR}$ Unico 2100 spectrophotometer (United Products and Instruments Inc., Shanghai, China). A golden yellow color indicated the presence of flavonoids. Total flavonoid contents were calculated as the rutin hydrate (minimum 98\%; Sigma Chemicals Co., St. Louis, MO, USA) equivalent using the mathematical equation described by Ordonez et al. [42].

2.4.8. Determination of Total Proanthocyanidin Contents in CVE. Total proanthocyanidin (tannin) content in CVE was estimated by the method of Sun et al. [43]. $0.5 \mathrm{ml}$ of $50 \mathrm{mg} / \mathrm{l}$ of the extract was mixed in $3 \mathrm{ml}$ of $4 \%$ vanillin-methanol solution and $1.5 \mathrm{ml}$ of concentrated hydrochloric acid, and the mixture was allowed to stand for 15 minutes at room temperature $\left(28^{\circ} \mathrm{C}\right)$ for color development. The absorbance was measured at $500 \mathrm{~nm}$ using the ${ }^{\circledR}$ Unico 2100 spectrophotometer (United Products and Instruments Inc., Shanghai, China). Total proanthocyanidin contents were calculated as the catechin hydrate (minimum 98\%) (Sigma Chemicals Co., St. Louis, MO, USA) equivalent (mg/g) using the mathematical equation described by Sun et al. [43].

2.4.9. Determination of Total Phenols in CVE. Total phenol content in CVE was determined by the modified Folin-Ciocalteu method of Wolfe et al. [44]. An aliquot of each of CVE was mixed with $2.5 \mathrm{ml}$ of the Folin-Ciocalteu reagent (previously diluted with distilled water, $1: 10 \mathrm{v} / \mathrm{v}$ ) and $2 \mathrm{ml}$ of $(75 \mathrm{~g} / \mathrm{l})$ of sodium carbonate. The tubes were vortexed for 15 seconds and allowed to stand for 30 minutes at $40^{\circ} \mathrm{C}$ for color development. Absorbance was measured at $765 \mathrm{~nm}$ using the ${ }^{\circledR}$ Unico 2100 spectrophotometer (United Products and Instruments Inc., Shanghai, China). This 
procedure was replicated thrice. Total phenolic content was calculated and expressed as the $\mathrm{mg} / \mathrm{g}$ rutin equivalent as earlier described by Wolfe et al. [44].

\subsection{In Vitro Antioxidant Profiling of CVE}

2.5.1. Determination of DPPH-Scavenging Activity of CVE. The effect of $C V E$ was estimated using the method by LiyanaPathirana and Shahidi [45]. A solution of $0.135 \mathrm{mM} \mathrm{1,1-}$ diphenyl-2-picrylhydrazyl (DPPH) (Sigma Aldrich, St. Louis, USA) in methanol was prepared, and $1.0 \mathrm{ml}$ of this solution was mixed with $1.0 \mathrm{ml}$ of methanol containing $0.2-1.0 \mathrm{mg}$ of each extract. The reaction mixture was vortexed thoroughly and left in the dark at room temperature for $30 \mathrm{~min}$. The spectrophotometric absorbance of the mixture was measured at $517 \mathrm{~nm}$. The reference drug, vitamin C (Sigma Chemicals Co., St. Louis, USA), used was equally prepared at the same concentration, and the experiment was conducted in triplicate. The ability to scavenge the DPPH radical was calculated by the following equation:

$$
\text { DPPH radical - scavenging activity }(\%)=\frac{\left[\left(\mathrm{AbS}_{\text {control }}-\mathrm{AbS}_{\text {sample }}\right)\right]}{\mathrm{AbS}_{\text {control }}} \times 100,
$$

where $\mathrm{Abs}_{\mathrm{control}}=$ absorbance of DPPH radical + methanol and $\mathrm{Abs}_{\text {sample }}=$ absorbance of DPPH radical + sample extract/standard.

\subsubsection{Determination of Superoxide Anion and Nitric Oxide-} Scavenging Activities of CVE. Superoxide anion and nitric oxide-scavenging activities of $C V E$ were evaluated using the method by Sreejayan and Rao [46]. In both assaying methods, quercetin was used as the standard drug.

2.6. Spectral Studies of Secondary Metabolites in CVE Using Gas Chromatography-Mass Spectrometry. GC-MS analysis was performed using a $7820 \mathrm{~A}$ gas chromatograph coupled to a $5975 \mathrm{C}$ inert mass spectrometer (with triple axis detector) and an electron-impact source (Agilent Technologies, Santa Clara, CA 95051, USA). $0.5 \mathrm{~g}$ of CVE was suspended in ethanol to make a concentration of $100 \mathrm{mg} / \mathrm{ml}(\mathrm{w} / \mathrm{v})$, followed by filtration through Varian Bond Elute C18 solid-phase extraction to remove impurities. The stationary phase of separation of the compounds was carried out on a HP-5 capillary column coated with 5\% of phenyl methyl siloxane $(30 \mathrm{~m}$ length $\times 0.32 \mathrm{~mm}$ diameter $\times 0.25 \mu \mathrm{m}$ film thickness) (Agilent Technologies, Santa Clara, CA 95051, USA). The carrier gas used was GCgrade helium (99.999\% purity) at a constant flow rate of $1.573 \mathrm{ml} / \mathrm{min}$, an initial nominal pressure of $1.9514 \mathrm{psi}$, and at an average velocity of $46 \mathrm{~cm} / \mathrm{s}$. One microliter $(1 \mu \mathrm{l})$ of the samples was injected in the split-less mode at an injection temperature of $260^{\circ} \mathrm{C}$. Purge flow was $21.5 \mathrm{ml} / \mathrm{min}$ at $0.50 \mathrm{~min}$ with a total gas flow rate of $23.355 \mathrm{ml} / \mathrm{min}$; the gas saver mode was switched on. The oven was initially programmed at $60^{\circ} \mathrm{C}(1 \mathrm{~min})$ and then ramped at $4^{\circ} \mathrm{C} / \mathrm{min}$ to $110^{\circ} \mathrm{C}(3 \mathrm{~min})$, followed by temperature program rates of $8^{\circ} \mathrm{C} / \mathrm{min}$ to $260^{\circ} \mathrm{C}(5 \mathrm{~min})$ and $10^{\circ} \mathrm{C} / \mathrm{min}$ to $300^{\circ} \mathrm{C}(12 \mathrm{~min})$. Run time was $56.25 \mathrm{~min}$ with a $3 \mathrm{~min}$ solvent delay. The mass spectrometer was operated in the electron-impact ionization mode at $70 \mathrm{eV}$ with an ion source temperature of $230^{\circ} \mathrm{C}$, quadrupole temperature of $150^{\circ} \mathrm{C}$, and transfer line temperature of $280^{\circ} \mathrm{C}$. The mass spectrophotometer conditions are solvent delay of $3.00 \mathrm{~min}$, gain factor of 1.00 , and resulting EM voltage of 1859, and scanning of possible compounds was from m/z 30 to $550 \mathrm{amu}$ at a $2.62 \mathrm{~s} / \mathrm{scan}$ rate. Using computer searches on a National Institute Standard and Technology (NIST) 14 Mass Spectral Database and the Mass Spectral Search Program (Version 2.2) and comparing, the spectrum obtained through GC-MS compounds present in the CVE was identified. The spectrum of the unknown components was compared with the spectrum of known components stored in the NIST library to ascertain its chemical identity $[47,48]$.

2.7. Experimental Animals. Young adult male Wistar albino rats (aged 8-12 weeks and body weight: 130-190 g) used in this study were obtained from the Animal House of the Lagos State University College of Medicine, Ikeja, Lagos State, Nigeria, after an ethical approval (Protocol Identification Code: UERC/BMS/134 and UERC Approval Number: UERC/ASN/2019/1703) was obtained from the University of Ilorin Ethical Review Committee for Postgraduate Research. The rats were handled in accordance with international principles guiding the Use and Handling of Experimental Animals [49]. The rats were maintained on standard rat feed (Ladokun Feeds, Ibadan, Oyo State, Nigeria) and potable water which were made available ad libitum. The rats were maintained at an ambient temperature between 28 and $30^{\circ} \mathrm{C}$, humidity of $55 \pm 5 \%$, and standard (natural) photoperiod of approximately $12 / 12$ hours of alternating light and dark periodicity.

2.8. Measurement of Body Weight. The body weights of rats were taken on days 1 and 14 of the experiment and determined on a digital rodent weighing scale ( ${ }^{\circledR}$ Virgo Electronic Compact Scale, New Delhi, India). The obtained values were expressed in grams (g).

2.9. Induction of DOX-Induced Cardiotoxicity and Treatment of Rats. Prior to commencement of the experiment, rats were randomly allotted into 8 groups of 7 rats per group such 
that the weight difference between and within groups was not more than $\pm 20 \%$ of the average weight of the sample population of rats used for the study. However, the choice of the therapeutic dose range of 100,200 , and $400 \mathrm{mg} / \mathrm{kg} /$ day of $C V E$ was made based on the result of the preliminary studies conducted.

In this experimental repeated dose model which lasted for 14 days, Groups I rats which served as the untreated control were orally pretreated with $10 \mathrm{ml} / \mathrm{kg} /$ day of distilled water but equally treated with $2.5 \mathrm{mg} / \mathrm{kg}$ of doxorubicin hydrochloride ( ${ }^{\circledR}$ Celondoxily Injection 50, CELON Laboratories PVT. Limited, Gajularamaram, Ranga Reddy District-500 090, Telangana State, India) dissolved in $0.9 \%$ normal saline administered on alternate days for 14 days. Group II rats were orally treated with $200 \mathrm{mg} / \mathrm{kg} /$ day of CVE dissolved in 5\% DMSO distilled water (CVE being only partly soluble in water, DMSO an organosulfur polar aprotic and inert solvent that readily dissolves both polar and nonpolar compounds was used) but treated with $1 \mathrm{ml} / \mathrm{kg}$ of $0.9 \%$ normal saline administered intraperitoneally on alternate days for 14 days. Group III-Group VI rats were orally pretreated with $50 \mathrm{mg} / \mathrm{kg} /$ day, $100 \mathrm{mg} / \mathrm{kg} /$ day, $200 \mathrm{mg} / \mathrm{kg} / \mathrm{day}$, and $400 \mathrm{mg} / \mathrm{kg} /$ day of CVE dissolved in $5 \%$ DMSO distilled water 3 hours before treatment with $2.5 \mathrm{mg} /$ $\mathrm{kg}$ of doxorubicin in $0.9 \%$ normal saline administered intraperitoneally on alternate days for 14 days, respectively. Group VII rats which served as the positive control group were equally pretreated with $20 \mathrm{mg} / \mathrm{kg} /$ day of Vitamin C 3 hours before treatment with $2.5 \mathrm{mg} / \mathrm{kg}$ of doxorubicin in $0.9 \%$ normal saline administered intraperitoneally on alternate days for 14 days. Group VIII rats were the untreated normal rats and were orally pretreated with $10 \mathrm{ml} / \mathrm{kg} /$ day of distilled water 3 hours before treatment with $2.5 \mathrm{mg} / \mathrm{kg}$ of doxorubicin in $0.9 \%$ normal saline administered intraperitoneally on alternate days for 14 days (Table 1) [50,51]. The choice of vitamin $\mathrm{C}$ was made because it is a standard antioxidant agent, and its effect as a positive control was compared with other treatment groups.

2.10. Blood Sample Collection. On the $14^{\text {th }}$ day which was the last day of the experiment, the rats were weighed and later fasted overnight but drinking water was made available ad libitum. Rats were sacrificed, and whole blood samples were collected directly from the heart under inhaled diethyl ether anesthesia. Blood samples were carefully collected with the fine $21 \mathrm{G}$ Needle and $5 \mathrm{ml}$ Syringe (Hangzhou Longde Medical Products Co. Ltd., Hangzhou, China) without causing damage to the heart tissues. The rats' heart, liver, kidneys, and testes were identified, harvested, and weighed.

2.11. Biochemical Assays. Blood samples obtained directly from the heart chamber were allowed to clot and then centrifuged at $5000 \mathrm{rpm}$ to separate clear sera from the clotted blood samples. The clear samples were obtained for assays of the following biochemical parameters: serum cardiac troponin I, LDH, TG, TC, and cholesterol fractions (HDL-c, LDL-c, and VLDL-c). Serum lipids were assayed using methods by Tietz [52], while serum troponin I and $\mathrm{LDH}$ were estimated by standard bioassay procedures.

2.12. Calculation of AI and CRI. AI was calculated as LDL-c $(\mathrm{mg} / \mathrm{dl}) \div \mathrm{HDL}-\mathrm{c}(\mathrm{mg} / \mathrm{dl})$ [53], while CRI was calculated as TC $(\mathrm{mg} / \mathrm{dl}) \div$ HDL-c $(\mathrm{mg} / \mathrm{dl})$ [54].

\subsection{Determination of Antioxidant Activities in the Rat} Cardiac Tissues. After the rats were sacrificed humanely under inhaled diethyl ether, the heart was harvested en bloc. The heart was gently and carefully divided into two halves (each consisting of the atrium and ventricle) using a new surgical blade. The left half of the heart was briskly rinsed in ice cold $1.15 \% \mathrm{KCl}$ solution in order to preserve the oxidative enzyme activities of the heart before being placed in a clean sample bottle which itself was in an ice-pack-filled cooler. This is to prevent the breakdown of the oxidative stress enzymes in these organs.

2.13.1. Determination of SOD Activities in the Heart Tissues. Superoxide dismutase activity was determined by its ability to inhibit the auto-oxidation of epinephrine by the increase in absorbance at $480 \mathrm{~nm}$ as described by Paoletti et al. [55]. Enzyme activity was calculated by measuring the change in absorbance at $480 \mathrm{~nm}$ for 5 minutes.

2.13.2. Determination of CAT Activities in the Heart Tissues. Tissue CAT activities were determined by the method described by Hadwan [56]. The specific activity of CAT was expressed as $\mathrm{U} / \mathrm{ml}$.

2.13.3. Determination of GSH, GPx, and GST Activities in the Heart Tissues. The reduced glutathione (GSH) content in the heart tissue was estimated according to the method described by Rahman et al. [57]. To the homogenate, $10 \%$ TCA was added and centrifuged. One millilitre of the supernatant was treated with $0.5 \mathrm{ml}$ of Elman's reagent (19.8 $\mathrm{mg}$ of 5, 5-dithiobisnitro benzoic acid (DTNB) in $100 \mathrm{ml}$ of $0.1 \%$ sodium nitrate) and $3.0 \mathrm{ml}$ of phosphate buffer (0.2 M, pH 8.0). The absorbance was read at $412 \mathrm{~nm}$. Similarly, GPx and GST activities were determined using the method by Faraji et al. [58] and Vontas et al. [59].

2.13.4. Determination of MDA Activities in the Heart Tissues. Method by Buege and Aust [60] was adopted in determining MDA activities in the cardiac tissue. One millilitre of the supernatant was added to $2 \mathrm{ml}$ of $(1: 1: 1$ ratio) the TCATBA- $\mathrm{HCl}$ reagent (thiobarbituric acid $0.37 \%, 0.24 \mathrm{~N} \mathrm{HCl}$, and $15 \%$ TCA) boiled at $100^{\circ} \mathrm{C}$ for 15 minutes and allowed to cool. Flocculent material was removed by centrifuging at $3000 \mathrm{rpm}$ for ten minutes. The supernatant was removed, and the absorbance was read at $532 \mathrm{~nm}$ against a blank. MDA was calculated using the molar extinction for the MDATBA-complex of $1.56 \times 10^{5} \mathrm{~m}^{-1} \cdot \mathrm{cm}^{-1}$. 
TABLE 1: Group treatment of rats.

\begin{tabular}{|c|c|}
\hline Groups & Treatments \\
\hline Group I & $\begin{array}{c}10 \mathrm{ml} / \mathrm{kg} \text { of distilled water p.o. for } 14 \text { days }+2.5 \mathrm{mg} / \mathrm{kg} \text { of doxorubicin hydrochloride in } 0.9 \% \text { normal saline given i.p. on } \\
\text { alternate days for } 14 \text { days }\end{array}$ \\
\hline Group II & $\begin{array}{c}200 \mathrm{mg} / \mathrm{kg} / \text { day of Clerodendrum volubile ethanol leaf extract in } 5 \% \text { DMSO-distilled water p.o. for } 14 \text { days }+1 \mathrm{ml} / \mathrm{kg} \text { of } 0.9 \% \\
\text { normal saline given i.p. on alternate days for } 14 \text { days }\end{array}$ \\
\hline Group III & $\begin{array}{c}50 \mathrm{mg} / \mathrm{kg} / \text { day of Clerodendrum volubile ethanol leaf extract in } 5 \% \text { DMSO-distilled water p.o. for } 14 \text { days }+2.5 \mathrm{mg} / \mathrm{kg} \text { of } \\
\text { doxorubicin hydrochloride in } 0.9 \% \text { normal saline given i.p. on alternate days for } 14 \text { days }\end{array}$ \\
\hline Group IV & $\begin{array}{c}100 \mathrm{mg} / \mathrm{kg} / \text { day of Clerodendrum volubile ethanol leaf extract in } 5 \% \text { DMSO-distilled water p.o. for } 14 \text { days }+2.5 \mathrm{mg} / \mathrm{kg} \mathrm{of} \\
\text { doxorubicin hydrochloride in } 0.9 \% \text { normal saline given i.p. on alternate days for } 14 \text { days }\end{array}$ \\
\hline Group V & $\begin{array}{c}200 \mathrm{mg} / \mathrm{kg} / \mathrm{day} \text { of Clerodendrum volubile ethanol leaf extract in } 5 \% \text { DMSO-distilled water p.o. for } 14 \text { days }+2.5 \mathrm{mg} / \mathrm{kg} \text { of } \\
\text { doxorubicin hydrochloride in } 0.9 \% \text { normal saline given i.p. on alternate days for } 14 \text { days }\end{array}$ \\
\hline Group VI & $\begin{array}{c}400 \mathrm{mg} / \mathrm{kg} / \text { day of Clerodendrum volubile ethanol leaf extract in } 5 \% \text { DMSO-distilled water p.o. for } 14 \text { days }+2.5 \mathrm{mg} / \mathrm{kg} \text { of } \\
\text { doxorubicin hydrochloride in } 0.9 \% \text { normal saline given i.p. on alternate days for } 14 \text { days }\end{array}$ \\
\hline Group VII & $\begin{array}{c}20 \mathrm{mg} / \mathrm{kg} / \text { day of vitamin } \mathrm{C} \text { in distilled water p.o. for } 14 \text { days }+2.5 \mathrm{mg} / \mathrm{kg} \text { of doxorubicin hydrochloride in } 0.9 \% \text { normal saline } \\
\text { given i.p. on alternate days for } 14 \text { days }\end{array}$ \\
\hline $\begin{array}{l}\text { Group } \\
\text { VIII }\end{array}$ & $10 \mathrm{ml} / \mathrm{kg} /$ day of distilled water p.o. for 14 days $+1 \mathrm{ml} / \mathrm{kg}$ of $0.9 \%$ normal saline given i.p \\
\hline
\end{tabular}

2.13.5. Histopathological Studies of the Heart. Using the remaining equally divided harvested heart, the right halves of the six randomly selected rats from each treatment and control groups were subjected to histopathological examinations, with the right ventricle being the most susceptible to doxorubicin toxicity of the heart chambers. After rinsing in normal saline, the dissected right half was preserved in $10 \%$ formo-saline before it was completely dehydrated in absolute $(100 \%)$ ethanol. It was then embedded in routine paraffin blocks. From the embedded paraffin blocks, 4-5 $\mu \mathrm{m}$ thick sections of the tissue were prepared and stained with the hematoxylin-eosin stain. These were examined under a photomicroscope (Model N-400 ME, CEL-TECH Diagnostics, Hamburg, Germany) connected with a host computer. Sections were illuminated with white light from a $12 \mathrm{~V}$ halogen lamp $(100 \mathrm{~W})$ after filtering with a $520 \mathrm{~nm}$ monochromatic filter. The slides were examined for associated histopathological lesions [61].

2.14. Statistical Analysis. Data were presented as mean\pm SEM of four and seven observations for the in vitro and in vivo studies, respectively. Statistical analysis was done using two-way analysis of variance, followed by a post hoc test, Student-Newman-Keuls test, on GraphPad Prism Version 5. Statistical significance was considered at $p<0.05, p<0.01$, and $p<0.001$.

\section{Results}

3.1. \%yield. Complete extraction of the pulverized dry leaf sample of Clerodendrum volubile in absolute ethanol was calculated to be $8.39 \%$. The resultant residue was a dark color, sticky, jelly-like, and sweet-smelling (bland) residue which was not completely soluble in water but completely soluble in methanol and ethanol.

\subsection{Qualitative Phytochemical Analysis of CVE.} Phytochemical analysis of CVE showed the presence of flavonoids, alkaloids, reducing sugars, and cardiac glycosides, while saponins, tannins, phenols, phlobatannins, steroids, and terpenoids were absent.

3.3. Quantitative Analysis of CVE. Table 2 shows the estimates of each of the secondary metabolites present in $100 \mathrm{mg}$ of CVE. As indicated in Table 2, CVE contains flavonoids $(34.79 \pm 0.37 \mathrm{mg} / 100 \mathrm{mg}$ of the dry extract), alkaloids $(36.73 \pm 0.27 \mathrm{mg} / 100 \mathrm{mg}$ of the dry extract), reducing sugars $(07.78 \pm 0.09 \mathrm{mg} / 100 \mathrm{mg}$ of the dry extract), and cardiac glycosides $(24.55 \pm 0.12 \mathrm{mg} / 100 \mathrm{mg}$ of the dry extract).

\subsection{Spectral Studies of Secondary Metabolites in CVE Using} Gas Chromatography-Mass Spectrometry. Figure 1 depicts the presence and relative abundance of thirty (30) different secondary metabolites in CVE obtained through gas chromatography-mass spectrometry, while the relatively abundant secondary metabolites present in CVE obtained through the phytoscan based on the CAS Library search include 9,12,15octadecatrienoic acid (otherwise known as) (Z,Z,Z)-9,12,15octadecatrienoic acid and (Z,Z,Z)-9,12,15-octadecatrienal (9.02\%); urea, triethyl-urea (5.74\%); 7-octadecenoic acid methyl ester and 9-octadecenoic acid methyl ester (5.61\%); n-hexadecanoic acid (5.39\%); ethyl- $\alpha$-d-glucopyranoside, ethyl- $\beta$-d-glucopyranoside, and methyl- $\beta$-d-arabinopyranoside $(5.13 \%) ; 9,12,15$-octadecatrienoic acid and (Z,Z,Z)-ethyl9,12,15-octadecatrienoate (4.08\%); phytol (3.28\%); hexadecanoic acid, methyl ester (3.25\%); methyl tetradecanoate $(2.18 \%)$; glycine, N,N-dimethyl-, methyl ester and N,Ndimethyl-3-methoxypropylamine (2.16\%); hexadecanoic acid, ethyl ester (2.03\%); benzoic acid, 4-methoxy-benzoic acid, and 4-methoxy-benzoic acid 4-methoxy-(1.77\%); 4-acetylanisole and 3-methoxyacetophenone (1.56\%); 6-hydroxy4,4,7 $\alpha$-trimethyl-5,6,7,7 $\alpha$-tetrahydrobenzofuran-2 $(4 \mathrm{H})$-one (1.36\%); guaifenesin and 2-cyclohexen-1-one, 4-hydroxy3,5, 6-trimethyl-4-(3-oxo-1-butenyl)-(1.32\%); phthalic acid, di(2-propylpentyl) ester, phthalic acid, di(oct-3-yl) ester, and diisooctyl phthalate (1.19\%); n-propyl 9,12,15-octadecatrienoate and 7,10,13-hexadecatrienoic acid (1.02\%) (Table 3). 
TABLE 2: Quantitative analysis of the secondary metabolites in CVE (mg/100 mg of the dry extract sample).

\begin{tabular}{lc}
\hline Secondary metabolite & Quantity $(\mathrm{mg} / 100 \mathrm{mg}$ of dry extract) \\
\hline Flavonoids & $34.79 \pm 0.37$ \\
Alkaloids & $36.73 \pm 0.27$ \\
Reducing sugars & $07.78 \pm 0.09$ \\
Cardiac glycosides & $24.55 \pm 0.12$ \\
\hline
\end{tabular}

\subsection{In Vitro Antioxidant Profiling of CVE}

3.5.1. Determination of DPPH-Scavenging Activity of CVE. Table 4 shows the in vitro DPPH-scavenging activities of $25 \mu \mathrm{g} / \mathrm{ml}, 50 \mu \mathrm{g} / \mathrm{ml}, 70 \mu \mathrm{g} / \mathrm{ml}$, and $100 \mu \mathrm{g} / \mathrm{ml}$ of $C V E$ in comparison with those of corresponding doses of the standard antioxidant drug (vitamin C) used. As shown, the DPPH-scavenging activities of the extract were significantly $(p<0.001)$ dose related and comparable to those of vitamin $\mathrm{C}$.

3.5.2. Determination of NO-Scavenging Activity of CVE. Table 5 shows the in vitro NO scavenging activities of $25 \mu \mathrm{g} /$ $\mathrm{ml}, 50 \mu \mathrm{g} / \mathrm{ml}, 70 \mu \mathrm{g} / \mathrm{ml}$, and $100 \mu \mathrm{g} / \mathrm{ml}$ of $C V E$ in comparison with those of corresponding doses of the standard antioxidant drug (vitamin C). As shown, NO-scavenging activities of the extract were significantly $(p<0.001)$ dose related and comparable to those of vitamin $\mathrm{C}$.

3.5.3. Determination of FRAP of CVE. Table 6 shows the in vitro ferric-reducing activity power of $25 \mu \mathrm{g} / \mathrm{ml}, 50 \mu \mathrm{g} / \mathrm{ml}$, $70 \mu \mathrm{g} / \mathrm{ml}$, and $100 \mu \mathrm{g} / \mathrm{ml}$ of $C V E$ in comparison with those of corresponding doses of the standard antioxidant drug. As shown, the FRAP activities of the extract were significantly $(p<0.001)$ dose dependent and comparable to those of the standard drug, vitamin C.

\subsection{Effect of CVE on the Average Body Weight of DOX-Treated} Rats. Table 7 shows the effect of repeated intraperitoneal DOX treatment and oral treatments with $50,100,200$, and $400 \mathrm{mg} / \mathrm{kg} /$ day of CVE on the average body weight on day 1 and day 15 as well as percentage weight change $(\% \Delta \mathrm{wt}$.) of rats repeatedly treated with doxorubicin and CVE for 14 days. As shown in Table 7, repeated intraperitoneal DOX treatment was associated with significant and profound $(p<0.0001)$ reduction in the weight gain pattern in the DOX only treated (Group I) rats when compared to untreated control (normal) rats (Group VIII). With repeated oral treatment of 50,100 , and $200 \mathrm{mg} / \mathrm{kg} / \mathrm{day}$ of $C V E$, there was a significant $(p<0.05$ and $p<0.0001)$ dose-dependent attenuation in the weight loss pattern in the extract-treated rats (Table 7). Vitamin C also had a similar effect on the weight gain pattern in the DOXtreated rats (Table 7).

3.7. Effect of CVE on the Cardiac Tissue Oxidative Stress Markers (GSH, GST, GPX, SOD, CAT, and MDA) of DOXTreated Rats. Repeated intraperitoneal injection of DOX to rats was associated with significant decreases $(p<0.05$ and $p<0.0001)$ in the activities of SOD, CAT, GPx, GST, and GSH levels while significantly increasing $(p<0.001)$ MDA activities (Table 8). However, repeated oral treatment with $C V E$ significantly $(p<0.05$ and $p<0.0001)$ attenuated the alterations in the activities of these enzyme markers in the cardiac tissue (Table 8).

3.8. Effect of CVE on Cardiac Marker Enzymes (LDH and Troponin I) of DOX-Treated Rats. Repeated intraperitoneal injection of DOX resulted in significant increases $(p<0.05$ and $p<0.0001$ ) in the serum LDH and troponin I levels when compared to that of untreated negative (control) values (Table 9). However, oral pretreatments with $50-400 \mathrm{mg} / \mathrm{kg} /$ day of $C V E$ significantly attenuated $(p<0.05$ and $p<0.0001)$ increases in the serum LDH and troponin I levels (Table 9). Oral pretreatment with $20 \mathrm{mg} / \mathrm{kg} /$ day of vitamin C caused similar effects as CVE on the serum $\mathrm{LDH}$ and troponin I (Table 9).

3.9. Effect of CVE on the Serum Lipid (TG, TC, HDL-c, LDL-c, and VLDL-c) Level of DOX-Treated Rats. Repeated intraperitoneal DOX injections resulted in significant $(p<0.0001)$ increases in the serum TG and VLDL-c concentrations, while there were no significant alterations in the serum HDL-c and LDL-c concentrations in the treated rats when compared to those of untreated rats (Table 10). However, in rats repeatedly pretreated with $50-400 \mathrm{mg} / \mathrm{kg} /$ day of $C V E$ orally, there were significant $(p<0.05$ and $p<0.0001)$ dose-unrelated decreases in the serum concentration of TG and VLDL-c without significant $(p>0.05)$ alterations in the serum concentration of HDL-c and LDL-c when compared to DOX only treated rats (Table 10). It is also noteworthy that vitamin $\mathrm{C}$ had similar pattern of effects on the measured serum lipid parameters (Table 10).

3.10. Effect of CVE on Cardiovascular Risk Indices (AI and $C R I)$ of DOX-Treated Rats. Repeated intraperitoneal injections with DOX resulted in a significant $(p<0.05)$ increase in the CRI value, while they had no significant effect on AI (Table 11). However, with pretreatment with $50-400 \mathrm{mg} / \mathrm{kg} /$ day of $C V E$ orally, there were further significant $(p<0.05)$ dose-unrelated decreases in the CRI value without significant alterations in the AI values (Table 11). Oral pretreatments with $20 \mathrm{mg} / \mathrm{kg} /$ day of vitamin $\mathrm{C}$ had a similar pattern on the AI and CRI as exhibited by CVE (Table 11).

3.11. Histopathological Studies of the Effect of CVE on DOXTreated Heart. Figure 2 is a microphotograph of a crosssectional representative of DOX only treated heart showing myocyte congestion with scanty pyknotic and predominant hyperchromatic and meganuclei with interstitial fibrosis, suggestive of myocardial hypertrophy when compared to normal untreated heart tissue with normal cardiac architecture (Figure 3). However, 


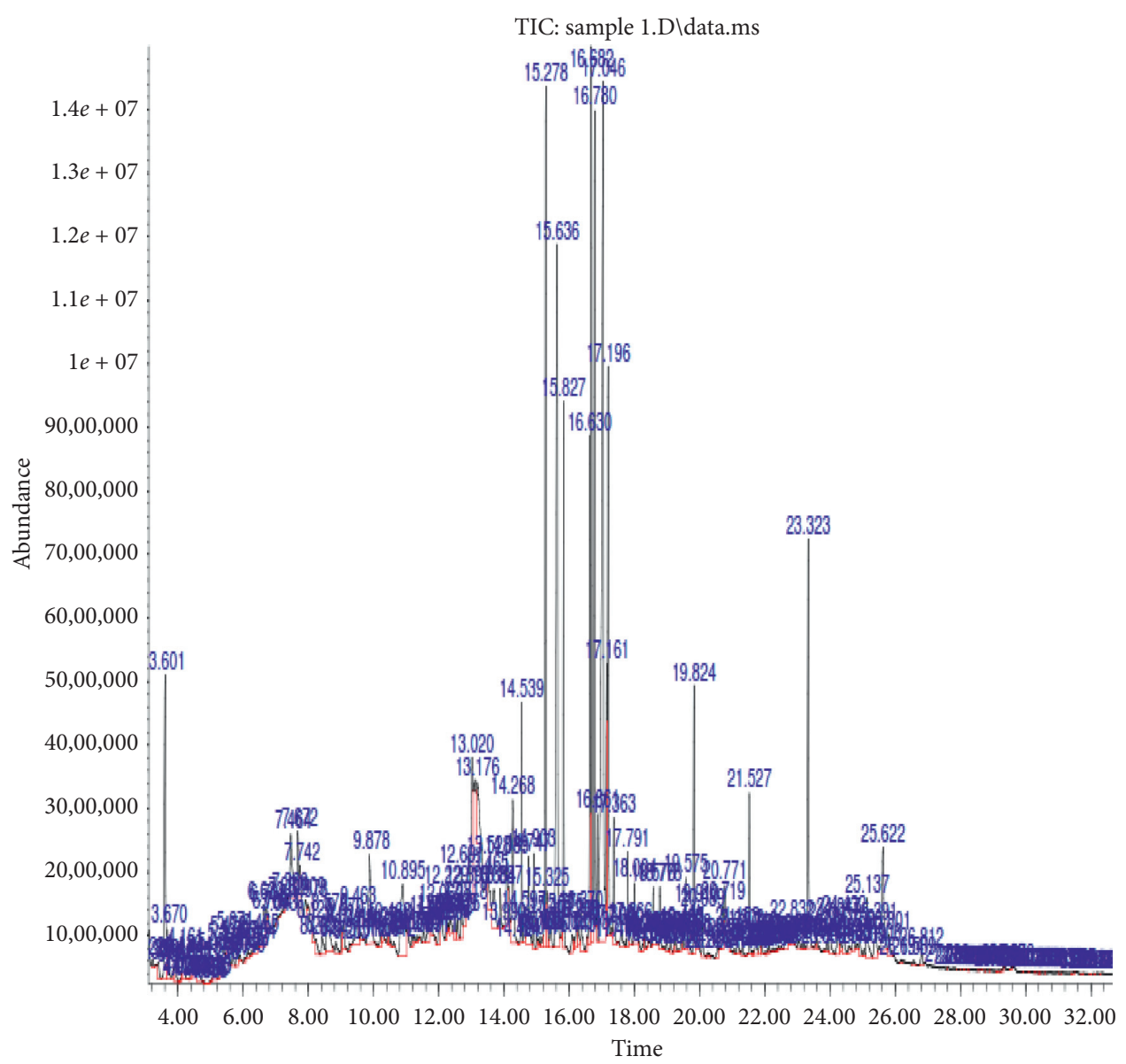

Figure 1: Mass spectrometry of the Clerodendrum volubile ethanol leaf extract (CVE) indicating molecular weights of each of the secondary metabolites and their relative abundance.

pretreatment with varying doses of CVE resulted in doserelated improvements in the histological distortions induced by DOX, especially at $200 \mathrm{mg} / \mathrm{kg} /$ day (Figure 4 ) and $400 \mathrm{mg} / \mathrm{kg} /$ day of CVE (Figure 5). On the contrary, there were histological features of mild congestion and scattered cardiac myocyte necrosis in rats pretreated with $20 \mathrm{mg} / \mathrm{kg} /$ day of vitamin $\mathrm{C}$, suggesting persisting histological lesions induced by doxorubicin treatment even in the face of treatment with the standard antioxidant, vitamin C (Figure 6).

\section{Discussion}

DOX is a 14-hydroxylated congener of daunorubicin (the immediate biosynthetic DOX precursor) which acts by inhibiting the progression of topoisomerase II, an enzyme which relaxes supercoils in DNA for transcription, therefore inducing DNA double-strand breaks, especially in rapidly dividing cells, and resulting in DNA synthesis disruption [62]. DOX is known to accumulate majorly in the liver, the kidneys, and the heart [63]. However, the heart is highly susceptible to doxorubicin toxicity because of the high mitochondria-to-cardiomyocyte ratio, making it more susceptible to oxidative damage especially from semiquinone-type free radicals generated from DOX hepatic metabolism $[63,64]$. In addition, the heart has a low regenerative capacity, compared to other body organs $[63,65]$. These limiting factors make the heart susceptible to DOX-induced off-target cardiotoxicity, which is notoriously mediated by its highly reactive primary alcohol metabolite, doxorubicinol [66], leading to overwhelming oxidative stress and a compromised endogenous antioxidant system $[67,68]$. The ensuing oxidative stress affects the lysosomes, microfibrils, mitochondria, and the sarcoplasmic reticulum [69], resulting in increased apoptotic cardiac myocytes and eventual cardiac cell damage [70]. The resulting cardiac damage is indicated by profound increases in the circulating specific and reliable cardiac biomarkers such as CK-MB, AST, $\mathrm{Mb}$, IMA, PBNP, GPBB, troponin I, and LDH [71, 72]. Of these cardiac biomarkers, cardiotoxicity in this study was reliably measured using troponin I and LDH assays. Thus, the profound elevation in the serum activities of cardiac troponin I and LDH levels following doxorubicin treatment is a strong indication that DOX-induced cardiotoxicity was reliably established. The literature has it that doxorubicin induces its toxicity through generation of oxidative stress resulting in lipoperoxidation of the cardiac muscle with the ultimate leakage of troponin I and $\mathrm{LDH}$ into the serum [71-73]. Thus, our result is in complete agreement with reports of earlier studies by Al-Harthi et al. [73] and Ammar El-Sayed et al. [74]. The DOX-related biochemical changes were further corroborated by the histological features of congested myocytes with scanty pyknotic and predominant 
TABLE 3: Quantitative analysis of the secondary metabolites (PhytoScan) of the Clerodendrum volubile ethanol leaf extract (CVE) using gas chromatography-mass spectrometry.

\begin{tabular}{|c|c|c|c|c|c|}
\hline $\mathrm{Pk} \#$ & RT & Area (\%) & Library/ID ref\# & CAS\# & Quality \\
\hline \multirow{4}{*}{ (1) } & \multirow{4}{*}{3.601} & \multirow{4}{*}{2.16} & Glycine, N,N-dimethyl-, methyl ester & $8679007148-06-3$ & 86 \\
\hline & & & N,N-Dimethyl-3-methoxypropylamine & $8722020650-07-1$ & 80 \\
\hline & & & 2-Methyl-allyl ethyl ether & $1759000557-31-3$ & 50 \\
\hline & & & Dimethylaminomethyl-isopropyl-sulfide & $14996077422-33-4$ & 50 \\
\hline \multirow[t]{2}{*}{ (2) } & \multirow[t]{2}{*}{7.464} & \multirow[t]{2}{*}{5.74} & Urea, triethyl-urea & $21278019006-59-8$ & 50 \\
\hline & & & 5-Hydroxymethylfurfural & $11338000067-47-0$ & 93 \\
\hline \multirow[t]{2}{*}{ (3) } & \multirow[t]{2}{*}{8.579} & \multirow[t]{2}{*}{0.77} & 5-Hydroxymethylfurfural & $11339000067-47-0$ & 70 \\
\hline & & & 5-Hydroxymethylfurfural & $11337000067-47-0$ & 62 \\
\hline \multirow{3}{*}{ (4) } & \multirow{3}{*}{9.878} & \multirow{3}{*}{1.56} & 4-Acetylanisole & $25100000100-06-1$ & 94 \\
\hline & & & 3-Methoxyacetophenone & $25121000586-37-8$ & 76 \\
\hline & & & Benzoic acid & $26636000100-09-4$ & 96 \\
\hline \multirow[t]{3}{*}{ (5) } & \multirow[t]{3}{*}{10.895} & \multirow[t]{3}{*}{1.77} & 4-Methoxy-benzoic acid & $26633000100-09-4$ & 95 \\
\hline & & & 4-Methoxy-benzoic acid 4-methoxy & $26632000100-09-4$ & 93 \\
\hline & & & Megastigmatrienone & $56052038818-55-2$ & 99 \\
\hline \multirow[t]{3}{*}{ (6) } & \multirow[t]{3}{*}{12.691} & 0.50 & 1H-1,5-Benzodiazepine, 2,3,4,5-tetrahydro-2,2,4-trimethyl-phenol & $56033040358-38-1$ & 70 \\
\hline & & & 2-(1,1-Dimethyl-2-propenyl)-3,6-dimethyl- & $56097092617-73-7$ & 62 \\
\hline & & & Ethyl- $\alpha$-d-glucopyranoside & $72939019467-01-7$ & 74 \\
\hline (7) & 13.113 & 5.13 & Ethyl- $\beta$-d-glucopyranoside & $60076000709-50-2$ & 53 \\
\hline & & & Methyl- $\beta$-d-arabinopyranoside & $35240005328-63-2$ & 50 \\
\hline (8) & 13.528 & 2.18 & Methyl tetradecanoate & $104286000124-10-7$ & 74 \\
\hline (9) & 13.684 & 0.95 & Germacyclopentane & $36709004554-75-0$ & 53 \\
\hline (10) & 13.887 & 0.81 & Tetradecanoic acid & $91415000544-63-8$ & 97 \\
\hline (11) & 14.089 & 1.36 & 6-Hydroxy-4,4,7 $\alpha$-trimethyl-5,6,7,7 $\alpha$-tetrahydrobenzofuran-2(4H)-one & $61438073410-02-3$ & 93 \\
\hline & & & Guaifenesin & $62883000093-14-1$ & 72 \\
\hline (12) & 14.268 & 1.32 & 2-Cyclohexen-1-one, 4-hydroxy-3,5,6-trimethyl-4-(3-oxo-1-butenyl) & $85356077846-84-5$ & 64 \\
\hline & & & Neophytadiene & $138502000504-96-1$ & 99 \\
\hline (13) & 14.539 & 0.88 & Bicyclo[3.1.1] heptane & 17424 006876-13-7 & 55 \\
\hline & & & 2,6,6-Trimethyl-, (1.alpha.,2.beta.,5.alpha.)9-octadecyne & $111836035365-59-4$ & 53 \\
\hline & & & 9-Octadecen-1-ol & $128820000143-28-2$ & 70 \\
\hline (14) & 14.747 & 0.67 & (Z)-6-Octen-1-ol, 3,7-dimethyl & $51056000105-85-1$ & 70 \\
\hline & & & Formate-6-octen-1-ol,3,7-dimethyl-, formate & $51061000105-85-1$ & 70 \\
\hline (15) & 15.278 & 3.25 & Hexadecanoic acid, methyl ester & $130821000112-39-0$ & 98 \\
\hline (16) & 15.636 & 5.39 & n-Hexadecanoic acid & $117419000057-10-3$ & 99 \\
\hline (17) & 15.827 & 2.03 & Hexadecanoic acid, ethyl ester & $144309000628-97-7$ & 99 \\
\hline & & & 7-Octadecenoic acid, methyl ester & $155720057396-98-2$ & 99 \\
\hline (18) & 16.682 & 5.61 & 9-Octadecenoic acid, methyl ester & $155758001937-62-8$ & 99 \\
\hline & & & (E)-9-Octadecenoic acid, methyl ester & $155754001937-62-8$ & 99 \\
\hline (19) & 16.780 & 3.28 & Phytol & $155849000150-86-7$ & 98 \\
\hline & & & 9,12,15-Octadecatrienoic acid & $138418000463-40-1$ & 99 \\
\hline$(20)$ & 17.046 & 9.02 & $(\mathrm{Z}, \mathrm{Z}, \mathrm{Z})-9,12,15$-Octadecatrienoic acid & $138420000463-40-1$ & 99 \\
\hline & & & (Z,Z,Z)-9,12,15-Octadecatrienal & $123143026537-71-3$ & 91 \\
\hline & & & 9,12,15-Octadecatrienoic acid & $165643001191-41-9$ & 99 \\
\hline (21) & 17.196 & 4.08 & (Z,Z,Z)-Ethyl 9,12,15-octadecatrienoate & $1656271000336-77-4$ & 99 \\
\hline & & & $9,12,15$-Octadecatrienoic acid & $165642001191-41-9$ & 99 \\
\hline (23) & & & Ethyl-9-hexadecenoate & $142080054546-22-4$ & 89 \\
\hline (23) & 18.004 & 0.62 & Cyclopentadecanone, 2-hydroxy- & $102369004727-18-8$ & 70 \\
\hline & & & Hexadecanoic acid & $188252023470-00-0$ & 90 \\
\hline (24) & 19.575 & 0.54 & 2-Hydroxy-1-(hydroxymethyl)ethyl ester & $188251023470-00-0$ & 87 \\
\hline & & & Phthalic acid, di(2-propylpentyl)ester & $2334191000377-93-5$ & 91 \\
\hline$(25)$ & 19.824 & 1.19 & Phthalic acid, di(oct-3-yl) ester & $2333831000377-72-3$ & 80 \\
\hline & & & Diisooctyl phthalate & $233361000131-20-4$ & 74 \\
\hline & & & n-Propyl 9,12,15-octadecatrienoate & $1790971000336-79-4$ & 93 \\
\hline$(26)$ & 20.771 & 1.02 & 7,10,13-Hexadecatrienoic acid, methyl ester & $124916056554-30-4$ & 91 \\
\hline & & & Methyl (Z)-5,11,14,17-eicosatetraenoate & 177257 059149-01-8 & 90 \\
\hline$(27)$ & 21.527 & 0.68 & Squalene & $243222000111-02-4$ & 99 \\
\hline$(28)$ & 22.832 & 0.55 & Gamma-tocopherol & $245804007616-22-0$ & 95 \\
\hline (29) & 25.137 & 0.68 & 2-(4-Fluoro-phenyl)-4-(3-methyl-benzylidene)-4H-oxazol-5-one & $1409181000296-71-2$ & 55 \\
\hline$(30)$ & 25.801 & 0.52 & 4-Dehydroxy-N-(4,5-methylene dioxy-nitrobenzylidene) tyramine & $1572641000111-66-9$ & 53 \\
\hline
\end{tabular}

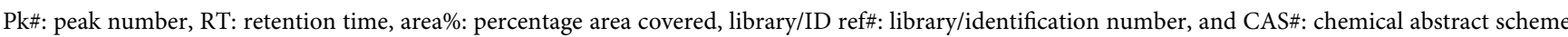
number. 
TABLE 4: In vitro DPPH-scavenging activity of $25-100 \mu \mathrm{g} / \mathrm{ml}$ of CVE and vitamin C.

\begin{tabular}{lcccc}
\hline \multirow{2}{*}{ Drug } & \multicolumn{4}{c}{ Graded doses $(\mu \mathrm{g} / \mathrm{ml})$} \\
& 25 & 50 & 75 & 100 \\
\hline CVE & $33.41 \pm 0.42$ & $47.10 \pm 0.63^{\mathrm{c}}$ & $60.69 \pm 0.52^{\mathrm{c}}$ & $76.25 \pm 0.32^{\mathrm{c}}$ \\
Vit. C & $45.05 \pm 0.48$ & $56.55 \pm 0.96^{\mathrm{c}}$ & $70.45 \pm 0.48^{\mathrm{c}}$ & $89.83 \pm 0.36^{\mathrm{C}}$ \\
\hline
\end{tabular}

${ }^{\mathrm{c}} \mathrm{A}$ significant increase at $p<0.001$.

TABLE 5: In vitro nitric oxide- (NO-) scavenging activity of $25-100 \mu \mathrm{g} / \mathrm{ml}$ of $C V E$ and vitamin C.

\begin{tabular}{lcccc}
\hline \multirow{2}{*}{ Drug } & \multicolumn{4}{c}{ Graded doses $(\mu \mathrm{g} / \mathrm{ml})$} \\
& 25 & 50 & 75 & 100 \\
\hline$C V E$ & $20.52 \pm 0.34$ & $49.32 \pm 0.57^{\mathrm{c}}$ & $64.97 \pm 0.34^{\mathrm{c}}$ & $78.57 \pm 0.57^{\mathrm{c}}$ \\
Vit. C & $47.38 \pm 0.26$ & $62.61 \pm 0.10^{\mathrm{c}}$ & $71.57 \pm 1.32^{\mathrm{c}}$ & $84.91 \pm 0.53^{\mathrm{c}}$ \\
\hline
\end{tabular}

${ }^{\mathrm{c}} \mathrm{A}$ significant increase at $p<0.001$.

TABle 6: In vitro FRAP activities of $25-100 \mu \mathrm{g} / \mathrm{ml}$ of $C V E$ and vitamin $\mathrm{C}$.

\begin{tabular}{lcccc}
\hline \multirow{2}{*}{ Drug } & \multicolumn{4}{c}{ Graded doses $(\mu \mathrm{g} / \mathrm{ml})$} \\
& 25 & 50 & 75 & 100 \\
\hline$C V E$ & $0.13 \pm 0.00$ & $0.24 \pm 0.00^{\mathrm{c}}$ & $0.33 \pm 0.00^{\mathrm{c}}$ & $0.41 \pm 0.00$ \\
Vit. C & $0.18 \pm 0.00$ & $0.40 \pm 0.00^{\mathrm{c}}$ & $0.51 \pm 0.00^{\mathrm{c}}$ & $0.66 \pm 0.00$ \\
\hline
\end{tabular}

${ }^{\mathrm{c}} \mathrm{A}$ significant increase at $p<0.001$.

TABLE 7: Effect of repeated oral treatment with $50-400 \mathrm{mg} / \mathrm{kg} /$ day of $C V E$ on the average body weight of DOX-treated rats.

\begin{tabular}{lccc}
\hline Group & Body wt. on day 1 (g) & Bodywt. on day 14 & $\% \Delta$ wt. \\
\hline I & $159.9 \pm 15.1$ & $143.1 \pm 19.0$ & $-10.7 \pm 04.7^{\mathrm{c}-}$ \\
II & $178.3 \pm 18.0$ & $191.1 \pm 20.6$ & $07.1 \pm 04.1^{\mathrm{c}+}$ \\
III & $144.2 \pm 15.8$ & $141.5 \pm 25.2$ & $-02.4 \pm 10.5^{\mathrm{a}+}$ \\
IV & $163.9 \pm 08.0$ & $153.0 \pm 11.0$ & $-06.6 \pm 04.8^{\mathrm{a}+}$ \\
V & $154.0 \pm 19.6$ & $151.6 \pm 23.1$ & $09.0 \pm 05.5^{\mathrm{c}+}$ \\
VI & $165.2 \pm 12.4$ & $147.9 \pm 12.8$ & $-10.6 \pm 05.8$ \\
VII & $151.3 \pm 12.9$ & $146.0 \pm 15.4$ & $-03.5 \pm 04.5^{\mathrm{a}+}$ \\
VIII & $163.8 \pm 16.8$ & $187.4 \pm 20.2$ & $14.5 \pm 06.2$ \\
\hline
\end{tabular}

${ }^{\mathrm{c}-} \mathrm{A}$ significant decrease at $p<0.0001$ when compared to the untreated (normal) negative control (Group VIII). ${ }^{\mathrm{c}+} \mathrm{A}$ significant increase at $p<0.0001$ when compared to the untreated (DOX-treated) negative control (Group I). ${ }^{\mathrm{a}+} \mathrm{A}$ significant increase at $p<0.05$ when compared to the untreated (DOX-treated only) negative control (Group I).

hyperchromatic and meganuclei with interstitial fibrosis, suggestive of myocardial hypertrophy. Again, this is in complete agreement with the report by Kwatra et al. [67]. However, profound attenuation in serum levels of troponin I and $\mathrm{LDH}$ following oral pretreatment with $50-400 \mathrm{mg} / \mathrm{kg} /$ day of $C V E$ is a clear demonstration of the protective potential of the extract against DOX-associated cardiotoxicity. Similarly, attenuations in the serum troponin I and LDH were also corroborated by the significant improvement in the histological architecture of the CVE-treated heart muscle especially at the oral dose of $400 \mathrm{mg} /$ $\mathrm{kg} /$ day of $C V E$ which showed no remarkable histological lesions in the CVE-treated heart.

Another notable finding in this current study is that the increased activities of the oxidative markers induced following doxorubicin treatment evident from marked increases in lipid peroxidation products (MDA) depleted reduced GSH levels and decreased SOD and CAT activities. GSH is considered to be the most important intracellular antioxidant system that is utilized for the inactivation of lipid peroxides through the activity of GPx, which generates GSSG as a byproduct [75]. It also plays a vital role in conjugating GST, which detoxifies the reactive substances of lipid peroxidation and other xenobiotics [76]. Therefore, GSH depletion leads to loss of cellular integrity and damage to macromolecules such as membrane lipids and also accumulation of its oxidized form (GSSG) which further leads to electrical and contractile dysfunction. DOX and its metabolites cause depletion of the cardiac GSH level, resulting in the consistent formation of oxygen-free radicals [77]. Similarly, SOD and CAT play a critical role in combating DOXinduced oxidative stress. Superoxide radicals generated at the site of damage can alter the SOD and CAT levels which may predispose to accumulation of the superoxide anion and in turn damage the myocardium. In the present study, it is suggested that DOX-induced massive free radical production which utilized the myocardium oxidative machinery that further leads to reduction in the activities of antioxidant enzymes via inhibition of enzyme protein biosynthesis. These results are consistent with those previously reported by Li et al. [78] and Mantawy et al. [79]. The fact that CVE treatment could significantly reduce the DOX-induced lipid peroxidation, raise the reduced GSH level, and increase the activities of SOD and CAT strongly indicates the profound antioxidant property of the extract which was further corroborated by the results of the in vitro antioxidant study. Already, the antioxidant and free radical-scavenging activities of $C V E$ are well documented [32, 80-82] Again, the literature has shown polyphenols (consisting of flavonoids, alkaloids, tannins, and anthocyanins) to freely scavenge free radicals in the body [83-86]. Among the secondary metabolites identified, the most prevailing compounds which have been reported for eliciting potent antioxidant activities for other plant extracts were tetradecanoic acid [87], n-hexadecanoic acid and hexadecanoic acid methyl and ethyl esters [88], phytol [89], and gamma-tocopherol [90]. These antioxidant compounds are known to possess redox properties through their free radical adsorption and neutralization [91, 92]. However, other reported pharmacological activities attributable to the identified secondary metabolites include anti-inflammatory, antimicrobial, cytotoxic, antihyperglycemic, hypocholesterolemic, and antiapoptotic activities $[93,94]$. Thus, the presence of these identified secondary metabolites in high amount as indicated by the results of quantitative analysis of $C V E$ undertaken in this study could be responsible for the prominent antioxidant/free radical scavenging and hypocholesterolemic activities, as well as profound improvement in the cardiovascular disease risk indices recorded in this study.

Other findings of significance are the profound increases in the serum TG, TC, and VLDL-c induced by DOX treatment. These findings are in tandem with those previously reported where prolonged treatment of experimental rats with DOX resulted in significant increases in the serum lipids, especially cholesterol and triglycerides [95-97]. The molecular mechanism of these lipid derangements has been reported to be mediated via downregulation of $\operatorname{PPAR} \gamma$, 
TABle 8: Antioxidant activities of $50-400 \mathrm{mg} / \mathrm{kg} /$ day of CVE in DOX-treated rat cardiac tissue.

\begin{tabular}{|c|c|c|c|c|c|c|}
\hline \multirow{2}{*}{ Groups } & \multicolumn{6}{|c|}{ Antioxidant parameters } \\
\hline & GSH & GST & $\mathrm{GPx}$ & SOD & CAT & MDA \\
\hline I & $88.1 \pm 5.3^{\mathrm{c}-}$ & $20.4 \pm 0.1^{\mathrm{c}-}$ & $81.7 \pm 4.9^{\mathrm{c}-}$ & $2.0 \pm 0.2^{\mathrm{a}-}$ & $13.3 \pm 1.7^{\mathrm{a}-}$ & $2.8 \pm 0.1$ \\
\hline II & $62.8 \pm 4.9^{\mathrm{f}-}$ & $21.4 \pm 0.9^{\mathrm{f}-}$ & $69.4 \pm 5.4$ & $2.2 \pm 0.1$ & $11.3 \pm 0.5$ & $2.1 \pm 0.3$ \\
\hline III & $51.2 \pm 2.8^{\mathrm{c}-}$ & $20.8 \pm 0.3^{\mathrm{f}-}$ & $51.5 \pm 3.1^{\mathrm{f}-}$ & $3.3 \pm 0.2$ & $17.9 \pm 1.1$ & $3.5 \pm 0.4$ \\
\hline IV & $77.6 \pm 5.7$ & $30.8 \pm 0.7^{\mathrm{c}+}$ & $81.4 \pm 5.4$ & $5.5 \pm 1.1^{\mathrm{c}+}$ & $35.6 \pm 4.1^{\mathrm{c}+}$ & $4.3 \pm 0.3^{\mathrm{b}+}$ \\
\hline $\mathrm{V}$ & $45.6 \pm 4.2^{\mathrm{c}^{-}}$ & $21.5 \pm 0.4^{\mathrm{f}-}$ & $50.3 \pm 4.6^{\mathrm{f}-}$ & $4.0 \pm 0.2^{\mathrm{a}+}$ & $21.8 \pm 1.6^{\mathrm{a}+}$ & $3.9 \pm 0.2^{\mathrm{a}+}$ \\
\hline VI & $65.7 \pm 4.3^{\mathrm{c}-}$ & $22.3 \pm 0.8^{\mathrm{f}-}$ & $64.6 \pm 4.0^{\mathrm{d}-}$ & $2.8 \pm 0.3$ & $19.6 \pm 0.7$ & $6.4 \pm 0.7^{\mathrm{c}+}$ \\
\hline VII & $112.6 \pm 2.3^{\mathrm{c}+}$ & $21.9 \pm 0.3^{\mathrm{f}-}$ & $111.1 \pm 2.3^{\mathrm{c}+}$ & $5.3 \pm 0.2^{\mathrm{c}+}$ & $40.2 \pm 1.7^{\mathrm{c}+}$ & $4.5 \pm 0.5^{\mathrm{b}+}$ \\
\hline VIII & $113.5 \pm 2.2$ & $23.6 \pm 0.4$ & $111.9 \pm 2.2$ & $2.5 \pm 0.2$ & $19.8 \pm 1.5$ & $2.4 \pm 0.2$ \\
\hline
\end{tabular}

${ }^{\mathrm{a}-\mathrm{c}-}$ Significant decreases at $p<0.05$ and $p<0.0001$, respectively, when compared to the untreated negative (normal) control value. ${ }^{\mathrm{c}+} \mathrm{A}$ significant increase at $p<0.0001$ when compared to the untreated negative (normal) control values. ${ }^{\mathrm{a}+\mathrm{b}+}{ }^{\circ}$ Significant increases at $p<0.05$ and $p<0.001$, respectively, when compared to the untreated negative (normal) control values. ${ }^{\mathrm{d}-\mathrm{f-}-}$ Significant decreases at $p<0.05$ and $p<0.0001$ when compared to the untreated positive (doxorubicin treated only) control values, respectively.

TABLE 9: Effect of 50-400 mg/kg/day of CVE on serum LDH and cardiac troponin I in DOX-intoxicated rats.

\begin{tabular}{lcc}
\hline Treatment groups & LDH $(\mathrm{U} / \mathrm{L})$ & Troponin I (ng/ml) \\
\hline I & $4204 \pm 637.1^{\mathrm{a}+}$ & $21.18 \pm 7.72^{\mathrm{c}+}$ \\
II & $3734 \pm 251.5$ & $3.29 \pm 2.41^{\mathrm{f}-}$ \\
III & $2781 \pm 657.5^{\mathrm{d}-}$ & $7.93 \pm 7.03^{\mathrm{d}-}$ \\
IV & $2939 \pm 184.1^{\mathrm{d}-}$ & $10.63 \pm 6.7^{\mathrm{d}-}$ \\
V & $2530 \pm 189.2^{\mathrm{d}-}$ & $2.96 \pm 1.71^{\mathrm{f}-}$ \\
VI & $2214 \pm 340.1^{\mathrm{d}-}$ & $3.53 \pm 1.84^{\mathrm{f}-}$ \\
VII & $2907 \pm 204.4^{\mathrm{d}-}$ & $3.46 \pm 1.71^{\mathrm{f}-}$ \\
VIII & $3331 \pm 227.5$ & $4.11 \pm 2.59$ \\
\hline
\end{tabular}

${ }^{\mathrm{a}+, \mathrm{c}+}$ Significant increases at $p<0.05$ and $p<0.0001$, respectively, when compared to the untreated negative (normal) control values. ${ }^{\mathrm{d}-\mathrm{f}-\mathrm{f}-}$ Significant decreases at $p<0.05$ and $p<0.0001$, respectively, when compared to the untreated positive (doxorubicin treated only) control values, respectively.

TABLE 10: Effect of $50-400 \mathrm{mg} / \mathrm{kg} /$ day of CVE on the serum lipid profile of DOX-treated rats.

\begin{tabular}{|c|c|c|c|c|c|}
\hline \multirow{2}{*}{ Groups } & \multicolumn{5}{|c|}{ Serum lipids } \\
\hline & TG $(\mathrm{mmol} / \mathrm{l})$ & TC $(\mathrm{mmol} / \mathrm{l})$ & HDL-c (mmol/l) & LDL-c (mmol/l) & VLDC-c $(\mathrm{mmol} / \mathrm{l})$ \\
\hline I & $1.3 \pm 0.1^{\mathrm{c}+}$ & $2.3 \pm 0.1^{\mathrm{a}+}$ & $0.6 \pm 0.0$ & $1.2 \pm 0.1$ & $1.3 \pm 0.1^{\mathrm{c}+}$ \\
\hline II & $0.8 \pm 0.2^{\mathrm{d}-}$ & $1.8 \pm 0.2^{\mathrm{d}-}$ & $0.6 \pm 0.0$ & $0.9 \pm 0.1^{\mathrm{d}-}$ & $0.4 \pm 0.1^{\mathrm{f}-}$ \\
\hline III & $0.8 \pm 0.1^{\mathrm{d}-}$ & $2.3 \pm 0.1$ & $0.7 \pm 0.0$ & $1.3 \pm 0.1$ & $0.5 \pm 0.1^{\mathrm{f}-}$ \\
\hline IV & $1.1 \pm 0.1$ & $2.3 \pm 0.1$ & $0.6 \pm 0.0$ & $1.2 \pm 0.1$ & $0.5 \pm 0.1^{\mathrm{f}-}$ \\
\hline $\mathrm{V}$ & $0.8 \pm 0.1^{\mathrm{d}-}$ & $2.3 \pm 0.1$ & $0.6 \pm 0.0$ & $1.3 \pm 0.1$ & $0.4 \pm 0.0^{\mathrm{f}-}$ \\
\hline VI & $1.0 \pm 0.1^{\mathrm{d}-}$ & $2.3 \pm 0.2$ & $0.6 \pm 0.0$ & $1.2 \pm 0.1$ & $0.5 \pm 0.1^{\mathrm{f}-}$ \\
\hline VII & $0.9 \pm 0.1^{\mathrm{d}-}$ & $2.1 \pm 0.1$ & $0.6 \pm 0.0$ & $1.1 \pm 0.1$ & $0.4 \pm 0.0^{f-}$ \\
\hline VIII & $0.6 \pm 0.1$ & $2.0 \pm 0.1$ & $0.6 \pm 0.0$ & $1.1 \pm 0.0$ & $0.3 \pm 0.0$ \\
\hline
\end{tabular}

${ }^{\mathrm{a}+, \mathrm{c}+}$ Significant increases at $p<0.5$ and $p<0.0001$, respectively, when compared to the untreated negative (normal) control value. ${ }^{\mathrm{d}-\mathrm{f}-}$ Significant decreases at $p<0.05$ and $p<0.0001$ when compared to the untreated positive (doxorubicin treated only) control values, respectively.

TABLE 11: Effect of 50-400 mg/kg/day of CVE on the atherogenic index (AI) and the coronary artery index (CRI) in DOX-intoxicated rats.

\begin{tabular}{lcc}
\hline Treatment groups & AI & CRI \\
\hline I & $2.1 \pm 0.1$ & $4.0 \pm 0.2^{\mathrm{a}+}$ \\
II & $1.6 \pm 0.2$ & $3.2 \pm 0.2^{\mathrm{e}-}$ \\
III & $2.0 \pm 0.2$ & $3.5 \pm 0.2^{\mathrm{d}-}$ \\
IV & $1.9 \pm 0.3$ & $3.9 \pm 0.3$ \\
V & $2.1 \pm 0.1$ & $3.8 \pm 0.1^{\mathrm{d}-}$ \\
VI & $2.0 \pm 0.1$ & $3.8 \pm 0.2^{\mathrm{d}-}$ \\
VII & $1.8 \pm 0.1$ & $3.8 \pm 0.2^{\mathrm{d}-}$ \\
VIII & $1.1 \pm 0.0$ & $3.5 \pm 0.1$ \\
\hline
\end{tabular}

${ }^{\mathrm{a}+} \mathrm{A}$ significant increase at $p<0.05$ when compared to the untreated negative (normal) control values. ${ }^{\mathrm{d}-\mathrm{e}-}$ Significant decreases at $p<0.05$ and $p<0.01$, respectively, when compared to the untreated positive (doxorubicin treated only) control values, respectively. 


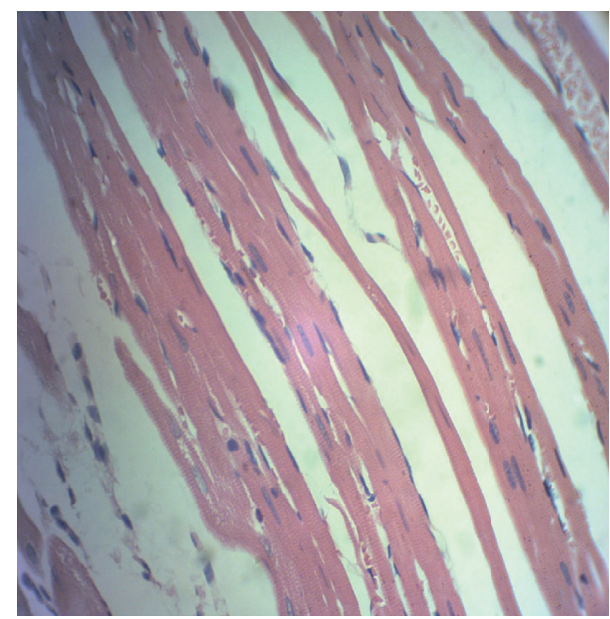

FIGURE 2: A cross-sectional representative of a DOX-intoxicated heart showing congested myocytes with scanty pyknotic and predominant hyperchromatic and meganuclei with interstitial fibrosis, suggestive of myocardial hypertrophy $(\times 400$ magnification, hematoxylin-eosin stain).

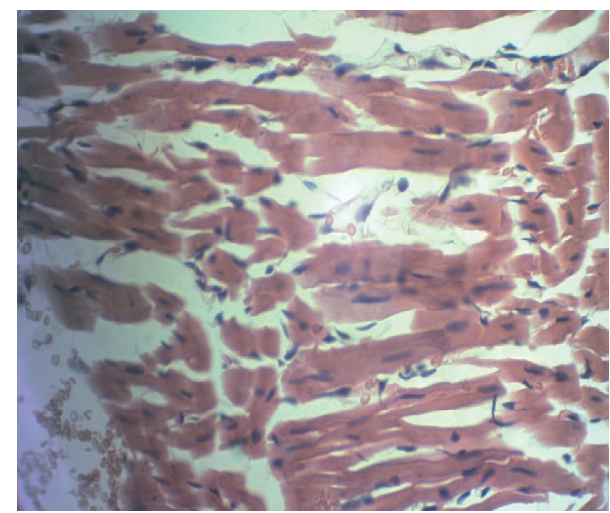

FIgURE 3: A cross-sectional representative of the normal rat heart showing normal cardiac architecture $(\times 400$ magnification, hematoxylin-eosin stain).

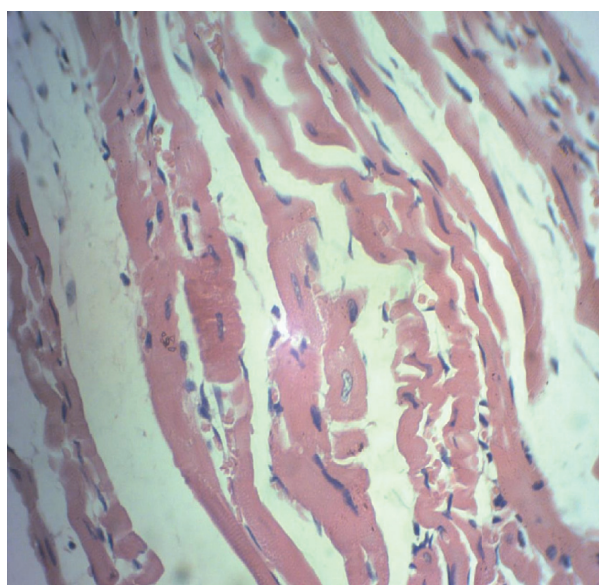

FIgURE 4: A cross-sectional representative of a DOX-intoxicated rat heart treated with $200 \mathrm{mg} / \mathrm{kg} /$ day CVE showing mildly congested myocytes with occasional meganuclei suggestive recovery from doxorubicin toxicity ( $\times 400$ magnification, hematoxylin-eosin stain).

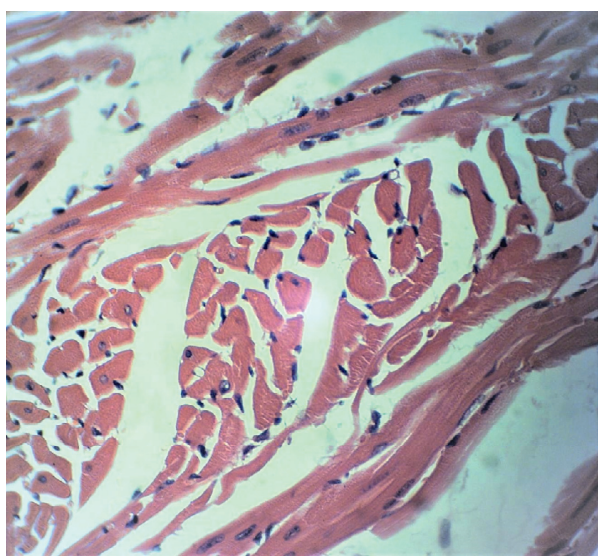

FIGURE 5: A photomicrograph of a cross-sectional representative of a DOX-intoxicated rat heart treated with $400 \mathrm{mg} / \mathrm{kg} / \mathrm{day} C V E$ showing near normal myocytes with very scanty meganuclei indicating no remarkable histological changes $(\times 400$ magnification, hematoxylin-eosin stain).

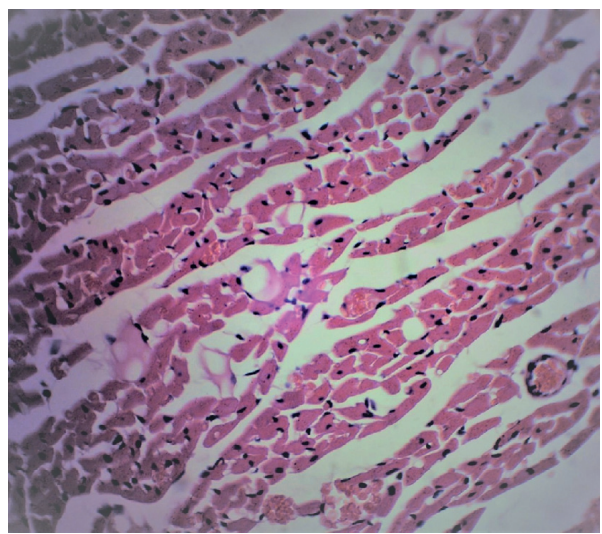

FIgURE 6: A photomicrograph of a cross-sectional representative of a doxorubicin-intoxicated rat heart treated with $20 \mathrm{mg} / \mathrm{kg} /$ day vitamin $\mathrm{C}$ showing mild congestion and scattered myocyte necrosis ( $\times 400$ magnification, hematoxylin-eosin stain).

mainly the white adipose tissue receptor, which regulates the expression of glucose and fatty acid transporters and plays a crucial role in lipid storage and glucose metabolism [98]. Thus, the downregulation of PPAR $\gamma$ inhibits blood glucose and lipid clearance, thereby causing hyperglycemia and hyperlipidemia [99]. Research studies have equally shown that derangements in the lipid profile predispose to cardiovascular diseases and increase the risk of major cardiovascular diseases such as ischemic heart disease and thrombotic stroke [100-103] which was corroborated in the present study by the profound increased CRI value, which itself is a reliable indicator of cardiovascular diseases, especially ischemic heart diseases. Drugs have also been reported to cause dyslipidemia-related heart diseases including doxorubicin $[103,104]$. It is equally well documented in the literature that a direct relationship exists between hypercholesterolemia and hyperlipidemia and atherosclerosis which is considered as a major cause of cardiovascular disease, especially coronary heart disease [105-107]. Thus, drugs including medicinal plants with 
hypolipidemic/antihyperlipidemic activities could equally be considered antiatherosclerotic and cardioprotective [108-110]. Thus, the hypolipidemic/antihyperlipidemic activity of CVE observed in this study is in tandem with those previously reported for Clerodendrum volubile and related species $[32,80,111-114]$. The fact that CVE profoundly lowered the serum TG, VLDL-c, and CRI is a further demonstration of the cardioprotective potential of CVE against DOX-induced cardiotoxicity and DOX-induced dyslipidemia which is similar to an earlier report by Kulkarni and Viswanatha-Swamy [115]. Thus, it is plausible for CVE to be lowering serum lipids and improving CRI value either by promoting its clearance from the body or inhibiting its de novo biosynthesis. Again, the serum lipid-lowering effect of $C V E$ is attributable to its high polyphenolic content which has been widely reported to attenuate dyslipidemia in different experimental models [79, 116, 117].

\section{Conclusions}

Overall, it can be safely concluded that $C V E$ offers protection in DOX-induced cardiotoxicity that was mediated via free radical-scavenging activity/antioxidant mechanism and improvements in the cardiovascular disease risk indices.

\section{Abbreviations}

$\begin{array}{ll}\text { AI: } & \text { Atherogenic index } \\ \text { AST: } & \text { Aspartate transaminase } \\ \text { CAT: } & \text { Catalase } \\ \text { CK-MB: } & \text { Creatine kinase } \\ \text { CRI: } & \text { Coronary artery index } \\ \text { CVE: } & \text { Clerodendrum volubile ethanol leaf extract } \\ \text { DMSO: } & \text { Dimethyl sulfoxide } \\ \text { DOX: } & \text { Doxorubicin } \\ \text { DPPH: } & \text { 1,1-Diphenyl-2-picrylhydrazyl } \\ \text { DTNB: } & \text { 5,5-Dithiobisnitro benzoic acid } \\ \text { GPBB: } & \text { Glycogen phosphorylase isoenzyme BB } \\ \text { GPx: } & \text { Glutathione peroxidase } \\ \text { GSH: } & \text { Reduced glutathione } \\ \text { GST: } & \text { Glutathione S-transferase } \\ \text { FRAP: } & \text { Ferric-reducing activity power } \\ \text { HCl: } & \text { Hydrochloric acid } \\ \text { HDL-c: } & \text { High-density lipoprotein cholesterol } \\ \text { IMA: } & \text { Ischemic modified albumin } \\ \text { i.p.: } & \text { Intraperitoneal } \\ \text { KCl: } & \text { Potassium chloride } \\ \text { LDH: } & \text { Lactate dehydrogenase } \\ \text { LDL-c: } & \text { Low-density lipoprotein cholesterol } \\ \text { MAD: } & \text { Malondialdehyde } \\ \text { Mb: } & \text { Myoglobin } \\ \text { NO: } & \text { Nitric oxide } \\ \text { PBNP: } & \text { Probrain natriuretic peptide } \\ \text { p.o.: } & \text { Per os } \\ \text { PPAR }: & \text { Peroxisome proliferator-activator receptor } \\ \text { SEM: } & \text { gamma } \\ \text { SOD: } & \text { Standard error of the mean } \\ \text { TBA: } & \text { Superoxidase dismutase } \\ & \text { Thiobarbituric acid } \\ & \end{array}$

$\begin{array}{ll}\text { TC: } & \text { Total cholesterol } \\ \text { TCA: } & \text { Tricarboxylic acid } \\ \text { TG: } & \text { Triglyceride } \\ \text { UNILORIN: } & \text { University of Ilorin } \\ \text { UV: } & \text { Ultraviolet } \\ \text { Vit. C: } & \text { Vitamin C } \\ \text { VLDL-c: } & \text { Very low-density lipoprotein cholesterol. }\end{array}$

\section{Data Availability}

The data used to support the study can be available upon request to the corresponding author.

\section{Conflicts of Interest}

The authors declare that they have no conflicts of interest.

\section{Authors' Contributions}

Olufunke Esan Olorundare designed the experimental protocol for this study and was involved in the manuscript writing; Adejuwon Adewale Adeneye supervised the research, analyzed data, and wrote the manuscript; Akinyele O. Akinsola is an M.Sc. student in Olufunke Esan Olorundare's laboratory who performed the laboratory research. The initial and ongoing work of isolating phytochemical principles from Clerodendrum volubile was performed in the laboratory of Mamoru Koketsu; Hasan Mukhtar is the collaborator in the USA who read through the manuscript.

\section{Acknowledgments}

The authors appreciate the technical assistance provided by the Process Manager, Dr. Obehiaghe A. King, the Laboratory Manager, Dr. Sarah John-Olabode, and other staff of the Laboratory Services, AFRIGLOBAL MEDICARE, Mobolaji Bank Anthony Branch Office, Ikeja, Lagos, Nigeria, in assaying for the serum cardiac biomarkers and lipid profile. Similarly, the technical support of staff of the LASUCOM Animal House, for the care of the Experimental Animals used for this study, and Mr. Sunday O. Adenekan of BIOLIFE CONSULTS in the area of oxidative stress marker analysis is much appreciated. In the same vein, the technical assistance of Mr. Innocent Okoye, a Senior Technologist in the Department of Oral Pathology and Medicine, Faculty of Dentistry, Lagos State University College of Medicine, Ikeja, Lagos, in the area of preparation of the slide for the histopathological studies is duly acknowledged. This research was funded by the Tertiary Education Trust Fund (TETFUND) Nigeria, through its National Research Fund (TETFUND/NRF/UIL/ILORIN/STI/VOL.1/B2.20.12), as a collaborative research award to both Professors Olufunke Esan Olorundare and Hasan Mukhtar.

\section{References}

[1] F. P. Guengerich, "Mechanisms of drug toxicity and relevance to pharmaceutical development," Drug Metabolism and Pharmacokinetics, vol. 26, no. 1, pp. 3-14, 2011. 
[2] C. V. Pereira, S. Nadanaciva, P. J. Oliveira, and Y. Will, "The contribution of oxidative stress to drug-induced organ toxicity and its detectionin vitroandin vivo," Expert Opinion on Drug Metabolism \& Toxicology, vol. 8, no. 2, pp. 219-237, 2012.

[3] Z. Lin and Y. Will, "Evaluation of drugs with specific organ toxicities in organ-specific cell lines," Toxicological Sciences, vol. 126, no. 1, pp. 114-127, 2012.

[4] A. N. Welz, A. Emberger-Klein, and K. Menrad, "Why people use herbal medicine: insights from a focus-group study in Germany," BMC Complementary and Alternative Medicine, vol. 18, no. 1, 2018.

[5] S.-Y. Pan, S.-F. Zhou, S.-H. Gao et al., "New perspectives on how to discover drugs from herbal medicine: CAM's outstanding contribution to modern therapeutics," EvidenceBased Complementary and Alternative Medicine, vol. 2013, Article ID 627375, 25 pages, 2013.

[6] N. A. Finn, H. W. Findley, and M. L. Kemp, "A switching mechanism in doxorubicin bioactivation can be exploited to control doxorubicin toxicity," PLoS Computational Biology, vol. 7, no. 9, Article ID e1002151, 2011.

[7] B. M. Razavi and G. Karimi, "Protective effect of silymarin against chemical-induced cardiotoxicity," Iran Journal of Basic Medical Sciences, vol. 19, no. 9, pp. 916-923, 2016.

[8] A. A. Oyagbemi, T. O. Omobowale, J. O. Olopade, and E. O. Farombi, "Kolaviron and Garcinia kola attenuate doxorubicin-induced cardiotoxicity in Wistar rats," Journal of Complementary and Integrative Medicine, vol. 15, no. 1, 2018.

[9] J. G. Omole, O. A. Ayoka, Q. K. Alabi et al., "Protective effect of kolaviron on cyclophosphamide-induced cardiac toxicity in rats," Journal of Evidence-Based Integrative Medicine, vol. 23, Article ID 2156587218757649, 2018.

[10] A. A. Adeneye and A. S. Benebo, "Protective effect of the aqueous leaf and seed extract of Phyllanthus amarus on gentamicin and acetaminophen-induced nephrotoxic rats," Journal of Ethnopharmacology, vol. 118, no. 2, pp. 318-323, 2008.

[11] R. Srirama, U. Senthilkumar, N. Sreejayan et al., "Assessing species admixtures in raw drug trade of Phyllanthus, a hepato-protective plant using molecular tools," Journal of Ethnopharmacology, vol. 130, no. 2, pp. 208-215, 2010.

[12] D. E. Peters, S. I. Omeodu, and E. B. Tege, "Effect of ethanolic leaves extract of Phyllantus amarus on cisplatin induced nephrotoxicity in albino rats," Journal of Applied Sciences and Environmental Management, vol. 19, no. 4, pp. 811-816, 2015.

[13] A. A. Adeneye, J. A. Olagunju, A. S. Benebo et al., "Nephroprotective effects of the aqueous root extract of Harungana madagascariensis (L.) in acute and repeated dose acetaminophen renal injured rats," International Journal of Applied Research in Natural Products, vol. 1, no. 1, pp. 6-14, 2008.

[14] B. Rajkapoor, B. Jayakar, S. Kavimani, and N. Murugesh, "Effect of dried fruits of Carica papaya Linn on hepatotoxicity," Biological \& Pharmaceutical Bulletin, vol. 25, no. 12 , pp. 1645-1646, 2002.

[15] O. Awodele, O. Yemitan, P. Ise, and V. Ikumawoyi, "Modulatory potentials of aqueous leaf and unripe fruit extracts of Carica papaya Linn. (Caricaceae) against carbon tetrachloride and acetaminophen-induced hepatotoxicity in rats," Journal of Intercultural Ethnopharmacology, vol. 5, no. 1, pp. 27-35, 2016.
[16] A. Atta, T. Elkoly, S. Mouneir, G. Kamel, N. Alwabel, and S. Zaher, "Hepatoprotective effect of methanol extracts of Zingiber officinale and Cichorium intybus," Indian Journal of Pharmaceutical Sciences, vol. 72, no. 5, pp. 564-570, 2010.

[17] B. V. S. Lakshmi and M. Sudhakar, "Protective effect of Zingiber officinale on gentamicin-induced nephrotoxicity in rats," International Journal of Pharmacology, vol. 6, no. 1, pp. 58-62, 2010.

[18] Y. Li, V. H. Tran, C. C. Duke et al., "Preventive and protective properties of Zingiber officinale (Ginger) in diabetes mellitus, diabetic complications, and associated lipid and other metabolic disorders: a brief review," Evidence-Based Complementary and Alternative Medicine, vol. 2012, Article ID 516870, 10 pages, 2012.

[19] D. A. Bardi, M. F. Halabi, N. A. Abdullah et al., "In vivo evaluation of ethanolic extract of Zingiber officinale rhizomes for its protective effect against liver cirrhosis," BioMedical Research International, vol. 2013, Article ID 918460, 10 pages, 2013.

[20] O. A. Adesanoye and E. O. Farombi, "Hepatoprotective effects of Vernonia amygdalina (Astereaceae) in rats treated with carbon tetrachloride," Experimental and Toxicologic Pathology, vol. 62, no. 2, pp. 197-206, 2010.

[21] A. Adeoye, A. Oyagbemi, T. Omobowale et al., "Nephroprotective effects of Vernonia amygdalina in alloxan-induced diabetes in rats," International Journal of Biochemistry Research \& Review, vol. 21, no. 1, pp. 1-15, 2018.

[22] M. Iwu and O. Igboko, "Flavonoids of Garcinia kola seeds," Journal of Natural Products, vol. 45, no. 5, pp. 650-651, 1982.

[23] A. Akintonwa and A. R. Essien, "Protective effects of Garcinia kola seed extract against paracetamol-induced hepatotoxicity in rats," Journal of Ethnopharmacology, vol. 29, no. 2, pp. 207-211, 1990.

[24] G. Varricchi, P. Ameri, C. Cadeddu et al., "Antineoplastic drug-induced cardiotoxicity: a redox perspective," Frontiers in Physiology, vol. 9, p. 167, 2018.

[25] S. Shah, M. Mohan, S. Kasture, M. Ballero, A. Maxia, and C. Sanna, "Protective effect ofHypericum hircinumon doxorubicin-induced cardiotoxicity in rats," Natural Product Research, vol. 27, no. 16, pp. 1502-1507, 2013.

[26] S. M. A. Shah, M. Akram, M. Riaz et al., "Cardioprotective potential of plant-derived molecules: a scientific and medicinal approach," Dose-Response, vol. 17, no. 2, Article ID $1559325819852243,2019$.

[27] T. Afsar, S. Rasak, A. Almajwal et al., "Evaluating the protective potency of Acacia hydaspica R. Parker on histological and biochemical changes induced by cisplatin in the cardiac tissues of rats," BMC Complementary and Alternative Medicine, vol. 19, no. 1, 2019.

[28] M. A. Hijazi, H. A. Jambi, B. M. Aljehany, and M. A. Althhaiban, "Potential protective effect of Achillea fragrantissima against Adriamycin-induced cardiotoxicity in rats via an antioxidant and anti-inflammatory pathway," BioMedical Research International, vol. 2019, Article ID 5269074, 10 pages, 2019.

[29] T. H. Ogunwa, S. A. Ajiboye, D. R. Sholanke et al., "Nutritional evaluation of Clerodendrum volubile (Marugbo) leaves," Asian Journal of Plant Science Research, vol. 5, no. 11, pp. 26-31, 2015.

[30] A. Fred-Jaiyesimi and A. Adekoya, "Pharmacognostic studies and anti-inflammatory activities of Clerodendrum volubile P Beauv leaf," International Journal of Phytomedicine, vol. 4, no. 3, pp. 414-418, 2012. 
[31] A. A.-n. Ajao, O. M. Oseni, O. T. Oladipo, Y. A. Adams, Y. O. Mukaila, and A. A. Ajao, "Clerodendrum volubile P. Beauv (Lamiaceae), an underutilized indigenous vegetable of utmost nutritive and pharmacological importance," BeniSuef University Journal of Basic and Applied Sciences, vol. 7, no. 4, pp. 606-611, 2018.

[32] O. L. Erukainure, R. M. Hafizur, N. Kabir et al., "Suppressive effects of Clerodendrum volubile P. Beauv. [Labiatae] methanolic extract and its fractions on type 2 diabetes and its complications," Frontiers in Pharmacology, vol. 9, p. 8, 2018.

[33] O. L. Erukainure, M. Z. Zaruwa, M. I. Choudhary et al., "Dietary fatty acids from leaves of clerodendrum volubile induce cell cycle arrest, downregulate matrix metalloproteinase-9 expression, and modulate redox status in human breast cancer," Nutrition and Cancer, vol. 68, no. 4, pp. 634-645, 2016.

[34] S. Afolabi, O. Olorundare, G. Gyebi G et al., "Cytotoxic potentials of Clerodendrum volubile against prostate cell lines and its possible proteomic targets," Journal of Clinical Nutrition and Food Sciences, vol. 2, no. 2, pp. 46-53, 2019.

[35] G. E. Trease and W. C. Evans, A Textbook of Pharmacognosy, Bailliere Tindall Ltd, London, UK, 1989.

[36] A. Sofowora, Medicinal Plants and Traditional Medicine in Africa, Spectrum Books Ltd, Ibadan, Nigeria, 1993.

[37] H. O. Edeoga, D. E. Okwu, D. E. Okwu, and B. O. Mbaebie, "Phytochemical constituents of some Nigerian medicinal plants," African Journal of Biotechnology, vol. 4, no. 7, pp. 685-688, 2005.

[38] J. B. Harborne, Phytochemical Methods, Chapman \& Hall, London, UK, 1973.

[39] T. P. Van-Burden and W. C. Robinson, "Formation of complexes between protein and tannic acid," Journal of Agricultural and Food Chemistry, vol. 17, no. 4, pp. 772-777, 1969.

[40] B. O. Obadoni and P. O. Ochuko, "Phytochemical studies and comparative efficacy of the crude extracts of some homeostatic plants in edo and delta states of Nigeria," Global Journal of Pure and Applied Sciences, vol. 8, no. 2, p. 203, 2002.

[41] P. S. Shaffer and M. Somogyi, "Copper-iodometric reagents for sugar determination," Journal of Biological Chemistry, vol. 100, pp. 695-713, 1933.

[42] A. Ordonez, J. Gomez, M. Vattuone, and M. Lsla, "Antioxidant activities of Sechium edule (jacq.) swartz extracts," Food Chemistry, vol. 97, no. 3, pp. 452-458, 2006.

[43] J.-S. Sun, Y.-H. Tsuang, I.-J. Chen, W.-C. Huang, Y.-S. Hang, and F.-J. Lu, "An ultra-weak chemiluminescence study on oxidative stress in rabbits following acute thermal injury," Burns, vol. 24, no. 3, pp. 225-231, 1998.

[44] K. Wolfe, X. Wu, and R. H. Liu, "Antioxidant activity of apple peels," Journal of Agricultural and Food Chemistry, vol. 51, no. 3, pp. 609-614, 2003.

[45] C. M. Liyana-Pathirana and F. Shahidi, "Antioxidant activity of commercial soft and hard wheat (Triticum aestivumL.) as affected by gastric $\mathrm{pH}$ conditions," Journal of Agricultural and Food Chemistry, vol. 53, no. 7, pp. 2433-2440, 2005.

[46] M. Sreejayan and M. N. A. Rao, "Nitric oxide scavenging by curcuminoids," Journal of Pharmacy and Pharmacology, vol. 49, no. 1, pp. 105-107, 1997.

[47] M. F. Cometa, S. Fortuna, G. Palazzino et al., "New cholinesterase inhibiting bisbenzylisoquinoline alkaloids from Abuta grandifolia," Fitoterapia, vol. 83, no. 3, pp. 476-480, 2012.
[48] H. J. Altameme, I. H. Hameed, and M. A. Kareem, "Analysis of alkaloid phytochemical compounds in the ethanolic extract of Datura stramonium and evaluation of antimicrobial activity," African Journal of Biotechnology, vol. 14, no. 19, pp. 1668-1674, 2015.

[49] National Research Council (US), "Committee for the update of the guide for the care and use of laboratory animals," Guide for the Care and Use of Laboratory Animals, The National Academies Press, Washington, DC, USA, 2011.

[50] M. Abu-Gazia and M. A. El-Magd, "Ameliorative effect of Cardamom aqueous extract on doxorubicin-induced cardiotoxicity in rats," Cells Tissues Organs, vol. 206, no. 1-2, pp. 62-72, 2018.

[51] R. A. Shaker, S. H. Abboud, H. C. Assad, and N. Hadi, "Enoxaparin attenuates doxorubicin induced cardiotoxicity in rats via interfering with oxidative stress, inflammation and apoptosis," BMC Pharmacology and Toxicology, vol. 19, no. 1, 2018.

[52] N. W. Tietz, Textbook of Clinical Chemistry, C. A. Burtis and E. R. Ashwood, Eds., W. B. Saunders, Philadephia, PA, USA, 1999.

[53] R. D. Abbott, P. W. Wilson, W. B. Kannel, and W. P. Castelli, "High density lipoprotein cholesterol, total cholesterol screening, and myocardial infarction. The framingham study," Arteriosclerosis: An Official Journal of the American Heart Association, Inc, vol. 8, no. 3, pp. 207-211, 1988.

[54] S. Alladi and K. R. Shanmugasundaram, "Induction of hypercholesterolemia by supplementing soy protein with acetate generating amino acids," Nutrition Reports International, vol. 40, pp. 893-899, 1989.

[55] F. Paoletti, D. Aldinucci, A. Mocali, and A. Caparrini, "A sensitive spectrophotometric method for the determination of superoxide dismutase activity in tissue extracts," Analytical Biochemistry, vol. 154, no. 2, pp. 536-541, 1986.

[56] M. H. Hadwan, "Simple spectrophotometric assay for measuring catalase activity in biological tissues," $B M C$ Biochemistry, vol. 19, no. 1, 2018.

[57] I. Rahman, A. Kode, and S. K. Biswas, "Assay for quantitative determination of glutathione and glutathione disulfide levels using enzymatic recycling method," Nature Protocols, vol. 1, no. 6, pp. 3159-3165, 2006.

[58] B. Faraji, H. K. Kang, and J. L. Valentine, "Methods compared for determining glutathione peroxidase activity in blood," Clinical Chemistry, vol. 33, no. 4, pp. 539-543, 1987.

[59] J. G. Vontas, A. A. Enayati, G. J. Small, and J. Hemingway, “A simple biochemical assay for glutathione $S$-transferase activity and its possible field application for screening glutathione $S$-transferase-based insecticide resistance," Pesticide Biochemistry and Physiology, vol. 68, no. 3, pp. 184-192, 2000.

[60] J. A. Buege and S. D. Aust, "[30] Microsomal lipid peroxidation," Methods in Enzymology, vol. 52, pp. 302-310, 1978.

[61] M. Slaoui and L. Fiette, "Histopathology procedures: from tissue sampling to histopathological evaluation," Methods in Molecular Biology, vol. 691, pp. 69-82, 2011.

[62] Y. Pommier, E. Leo, H. Zhang, and C. Marchand, "DNA topoisomerases and their poisoning by anticancer and antibacterial drugs," Chemistry \& Biology, vol. 17, no. 5, pp. 421-433, 2010.

[63] A. I. Abushouk, A. M. Abdosalem, A. Saad et al., "Mesenchymal stem cell therapy for doxorubicin-induced cardiomyopathy: potential mechanisms, governing factors, and implications of the heart stem cell debate," Frontiers in Pharmacology, vol. 10, Article ID 00635, 2019. 
[64] D. Edwardson, R. Narendrula, S. Chewchuk, K. MispelBeyer, J. Mapletoft, and A. Parissenti, "Role of drug metabolism in the cytotoxicity and clinical efficacy of anthracyclines," Current Drug Metabolism, vol. 16, no. 6, pp. 412-426, 2015.

[65] K. Kikuchi and K. D. Poss, "Cardiac regenerative capacity and mechanisms," Annual Review of Cell and Developmental Biology, vol. 28, no. 1, pp. 719-741, 2012.

[66] C. M. Schaupp, C. C. White, G. F. Merrill, and T. J. Kavanagh, "Metabolism of doxorubicin to the cardiotoxic metabolite doxorubicinol is increased in a mouse model of chronic glutathione deficiency: a potential role for carbonyl reductase 3," Chemico-Biological Interactions, vol. 234, pp. 154-161, 2015.

[67] M. Kwatra, V. Kumar, A. Jangra et al., “Ameliorative effect of naringin against doxorubicin-induced acute cardiac toxicity in rats," Pharmaceutical Biology, vol. 54, no. 4, pp. 637-647, 2016.

[68] D. Cappetta, A. De Angelis, L. Sapio et al., "Oxidative stress and cellular response to doxorubicin: a common factor in the complex milieu of anthracycline cardiotoxicity," Oxidative Medicine and Cellular Longevity, vol. 2017, Article ID 1521020, 13 pages, 2017.

[69] R. Ogura, M. Sugiyama, N. Haramaki, and T. Hidaka, "Electron spin resonance studies on the mechanism of adriamycin-induced heart mitochondrial damages," Cancer Research, vol. 51, no. 13, pp. 3555-3558, 1991.

[70] J. Shi, E. Abdelwahid, and L. Wei, "Apoptosis in anthracycline cardiomyopathy," Current Pediatric Reviews, vol. 7, no. 4, pp. 329-336, 2011.

[71] E. Vassiliadis, N. Barascuk, A. Didangelos et al., "Novel cardiac-specific biomarkers and the cardiovascular continuum," Biomarkers Insights, vol. 7, pp. 45-57, 2012.

[72] S. P. Rao, S. Miller, R. Rosenbaum et al., "Opportunities for microRNAs in the crowded field of cardiovascular biomarkers," Annual Review of Pathology: Mechanism of Disease, vol. 14, pp. 211-238, 2019.

[73] S. E. Al-Harthi, O. M. Alarabi, W. S. Ramadan et al., "Amelioration of doxorubicin-induced cardiotoxicity by resveratrol," Molecular Medicine Reports, vol. 10, no. 3, pp. 1455-1460, 2014.

[74] E.-S. M. Ammar, S. A. Said, S. L. El-Damarawy, and G. M. Suddek, "Cardioprotective effect of grape-seed proanthocyanidins on doxorubicin-induced cardiac toxicity in rats," Pharmaceutical Biology, vol. 51, no. 3, pp. 339-344, 2013.

[75] A. Ayala, M. F. Muñoz, and S. Argüelles, "Lipid peroxidation: production, metabolism, and signaling mechanisms of malondialdehyde and 4-hydroxy-2-nonenal," Oxidative Medicine and Cellular Longevity, vol. 2014, Article ID 360438, 31 pages, 2014.

[76] N. Allocati, M. Masulli, C. Di Ilio et al., "Glutathione transferases: substrates, inhibitors and pro-drugs in cancer and neurodegenerative diseases," Oncogenesis, vol. 7, no. 1, 2018.

[77] Y. Du, H. Guo, and H. Lou, "Grape seed polyphenols protect cardiac cells from apoptosis via induction of endogenous antioxidant enzymes," Journal of Agricultural and Food Chemistry, vol. 55, no. 5, pp. 1695-1701, 2007.

[78] T. Li, I. Danelisen, and P. K. Singal, "Early changes in myocardial antioxidant enzymes in rats treated with adriamycin," Molecular and Cellular Biochemistry, vol. 232, no. 12, pp. 19-26, 2002.
[79] E. M. Mantawy, W. M. El-Bakly, A. Esmat, A. M. Badr, and E. El-Demerdash, "Chrysin alleviates acute doxorubicin cardiotoxicity in rats via suppression of oxidative stress, inflammation and apoptosis," European Journal of Pharmacology, vol. 728, pp. 107-118, 2014.

[80] S. A. Adefegha and G. Oboh, "Antioxidant and inhibitory properties of Clerodendrum volubile leaf extracts on key enzymes relevant to non-insulin dependent diabetes mellitus and hypertension," Journal of Taibah University for Science, vol. 10, no. 4, pp. 521-533, 2016.

[81] O. R. Molehin, O. I. Oloyede, K. A. Idowu et al., "White butterfly (Clerodendrum volubile) leaf extract protects against carbon tetrachloride-induced hepatotoxicity in rats," Biomedicine \& Pharmacotherapy, vol. 96, pp. 924-929, 2017.

[82] J.-H. Wang, F. Luan, X.-D. He, Y. Wang, and M.-X. Li, "Traditional uses and pharmacological properties of Clerodendrum phytochemicals," Journal of Traditional and Complementary Medicine, vol. 8, no. 1, pp. 24-38, 2018.

[83] R. Pulido, L. Bravo, and F. Saura-Calixto, "Antioxidant activity of dietary polyphenols as determined by a modified ferric reducing/antioxidant power assay," Journal of Agricultural and Food Chemistry, vol. 48, no. 8, pp. 3396-3402, 2000.

[84] A. Scalbert, I. T. Johnson, and M. Saltmarsh, "Polyphenols: antioxidants and beyond," The American Journal of Clinical Nutrition, vol. 81, no. 1, pp. 215S-217S, 2005.

[85] L. Meng, Y. Lozano, E. Gaydou, and B. Li, “Antioxidant activities of polyphenols extracted from Perilla frutescens varieties," Molecules, vol. 14, no. 1, pp. 133-140, 2008.

[86] A. A. Adeneye, A. I. Oreagba, I. O. Ishola et al., "Evaluation of the anti-arthritic activity of the hydroethanolic leaf extract of Alchornea cordifolia in rats," African Journal of Traditional, Complementary \& Alternative Medicine, vol. 11, no. 2, pp. 402-410, 2014.

[87] A. Limmongkon, P. Janhom, A. Amthong et al., "Antioxidant activity, total phenolic, and resveratrol content in five cultivars of peanut sprouts," Asian Pacific Journal of Tropical Biomedicine, vol. 7, no. 4, pp. 332-338, 2017.

[88] S. Tian, Y. Sun, Z. Chen et al., "Functional properties of polyphenols in grains and effects of physicochemical processing on polyphenols," Journal of Food Quality, vol. 2019, Article ID 2793973, 8 pages, 2019.

[89] F. Mujeeb, P. Bajpai, and N. Pathak, "Phytochemical evaluation, antimicrobial activity, and determination of bioactive components from leaves of Aegle marmelos," Biomedicine Research International, vol. 2014, Article ID 497606, 11 pages, 2014

[90] G. Rajeswari, M. Murugan, and V. R. Mohan, "GC-MS analysis of bioactive components of Hugonia mystax L. (Linaceae)," Research Journal of Pharmaceutical, Biological and Chemical Sciences, vol. 3, no. 4, pp. 301-308, 2012.

[91] J. de Moraes, R. N. De Oliveira, J. P. Costa et al., "Phytol, a diterpene alcohol from chlorophyll, as a drug against neglected tropical disease Schistosomiasis Mansoni," PLOS Neglected Tropical Diseases, vol. 8, no. 1, p. e2617, 2014.

[92] V. M. D. Mambro, A. E. C. S. Azzolini, Y. M. L. Valim, and M. J. V. Fonseca, "Comparison of antioxidant activities of tocopherols alone and in pharmaceutical formulations," International Journal of Pharmaceutics, vol. 262, no. 1-2, pp. 93-99, 2003.

[93] A. Adedapo, F. Jimoh, and A. Afolayan, "Comparison of the nutritive value and biological activities of the acetone, methanol and water extracts of the leaves of Bidens pilosa and 
Chenopodium album," Acta Poloniae Pharmaceutica Drug Research, vol. 68, no. 1, pp. 83-92, 2011.

[94] B. Moyo, S. Oyedemi, P. J. Masika, and V. Muchenje, "Polyphenolic content and antioxidant properties of Moringa oleifera leaf extracts and enzymatic activity of liver from goats supplemented with Moringa oleifera leaves/sunflower seed cake," Meat Science, vol. 91, no. 4, pp. 441-447, 2012.

[95] Y. Yin, Y. He, W. Liu et al., "The durative use of suspension cells and callus for volatile oil by comparative with seeds and fruits in Capparis spinosa L," PLOS One, vol. 9, no. 11, Article ID e113668, 2014.

[96] W. Peng, D. Li, M. Zhang et al., "Characteristics of antibacterial molecular activities in poplar wood extractives," Saudi Journal of Biological Sciences, vol. 24, no. 2, pp. 399404, 2015.

[97] G. Koutinos, G. P. Stathopoulos, I. Dontas et al., "The effect of doxorubicin and its analogue mitoxantrone on cardiac muscle and on serum lipids: an experimental study," Anticancer Research, vol. 22, pp. 815-820, 2002.

[98] B. C. Koti, A. H. Vishwanathswamy, J. Wagawade, and A. H. Thippeswamy, "Cardioprotective effect of lipistat against doxorubicin induced myocardial toxicity in albino rats," Indian Journal of Experimental Biology, vol. 47, no. 1, pp. 41-46, 2009.

[99] A. Chennuru and M. T. S. Saleem, "Antioxidant, lipid lowering, and membrane stabilization effect of sesamol against doxorubicin-induced cardiomyopathy in experimental rats," BioMedical Research International, vol. 2013, Article ID 934239, 5 pages, 2013.

[100] Y.-S. Tsai and N. Maeda, "PPAR $\gamma$ : a critical determinant of body fat distribution in humans and mice," Trends in Cardiovascular Medicine, vol. 15, no. 3, pp. 81-85, 2005.

[101] S. Arunachalam, P. B. Tirupathi Pichiah, and S. Achiraman, "Doxorubicin treatment inhibits PPAR $\gamma$ and may induce lipotoxicity by mimicking a type 2 diabetes-like condition in rodent models," FEBS Letters, vol. 587, no. 2, pp. 105-110, 2013.

[102] H. Takano and I. Komuro, "Roles of peroxisome proliferatoractivated receptor $\gamma$ in cardiovascular disease," Journal of Diabetes and Its Complications, vol. 16, no. 1, pp. 108-114, 2002.

[103] J. O. Fatoki, O. T. Adedosu, O. K. Afolabi et al., "Dyslipidemic effect of doxorubicin and etoposide: a predisposing factor for the antineoplastic drugs-induced cardiovascular diseases," Research \& Reviews: Journal of Pharmacology and Toxicological Studies, vol. 6, no. 1, pp. 34-42, 2018.

[104] M. Henrik and M. K. Ito, Medication Induced Changes in Lipid and Lipoproteins, K. R. Feingold, B. Anawalt, A. Boyce et al., Eds., Endotext, South Dartmouth, MA, USA, 2018, https://www.ncbi.nlm.nih.gov/books/NBK326739/.

[105] K. Wouters, R. Shiri-Sverdloy, P. J. van Gorp et al., "Understanding hyperlipidemia and atherosclerosis: lessons from genetically modified apoe and ldlr mice," Clinical Chemistry and Laboratory Medicine, vol. 43, no. 5, pp. 470-479, 2005.

[106] L. Lacoste, J. Y. T. Lam, J. Hung, G. Letchacovski, C. B. Solymoss, and D. Waters, "Hyperlipidemia and coronary disease," Circulation, vol. 92, no. 11, pp. 3172-3177, 1995.

[107] J. Wang, K. He, C. Yang et al., "Dietary cholesterol is highly associated with severity of hyperlipidemia and atherosclerotic lesions in heterozygous LDLR-deficient Hamsters," International Journal of Molecular Sciences, vol. 20, no. 14, p. 3515, 2019.
[108] J.-Y. Kim and S. H. Shim, "Medicinal herbs effective against atherosclerosis: classification according to mechanism of action," Biomolecules \& Therapeutics, vol. 27, no. 3, pp. 254-264, 2019.

[109] N. Fidèle, B. Joseph, T. Emmanuel, and D. Théophile, "Hypolipidemic, antioxidant and anti-atherosclerogenic effect of aqueous extract leaves of Cassia. occidentalis linn (caesalpiniaceae) in diet-induced hypercholesterolemic rats," BMC Complementary and Alternative Medicine, vol. 17, no. 1, 2017.

[110] M. I. Qadir, A. Manzoor, and M. S. H. Akash, "Potential role of medicinal plants for anti-atherosclerosis activity," Bangladesh Journal of Pharmacology, vol. 13, no. 1, pp. 59-66, 2018.

[111] B. A. Akinpelu, J. T. Apata, E. O. Iwalewa et al., "Evaluation of anti-hyperlipdemic potential of ethanolic leaf extract of Clerodendrum volubile P. Beauv," IFE Journal of Science, vol. 18, no. 3, pp. 789-800, 2016.

[112] A. A. Adeneye, T. I. Adeleke, and A. K. Adeneye, "Hypoglycemic and hypolipidemic effects of the aqueous fresh leaves extract of Clerodendrum capitatum in Wistar rats," Journal of Ethnopharmacology, vol. 116, no. 1, pp. 7-10, 2008.

[113] R. Jadeja, M. Thounaojam, Ansarullah, R. Devkar, and A. Ramachandran, "Clerodendron glandulosum Coleb., Verbenaceae, ameliorates high fat diet-induced alteration in lipid and cholesterol metabolism in rats," Revista Brasileira de Farmacognosia, vol. 20, no. 1, pp. 117-123, 2010.

[114] R. N. Jadeja, M. C. Thounaojam, U. V. Ramani, R. V. Devkar, and A. V. Ramachandran, "Anti-obesity potential of Clerodendron glandulosum.Coleb leaf aqueous extract," Journal of Ethnopharmacology, vol. 135, no. 2, pp. 338-343, 2011.

[115] J. M. Kulkarni and A. H. M. Viswanatha-Swamy, "Cardioprotective effect of gallic acid against doxorubicin-induced myocardial toxicity in albino rats," KLE University of Health Sciences Journal, vol. 8, no. 1, pp. 28-35, 2015.

[116] A. C. Famurewa and F. E. Ejezie, "Polyphenols isolated from virgin coconut oil attenuates cadmium-induced dyslipidemia and oxidative stress due to their antioxidant properties and potential benefits on cardiovascular risk ratios in rats," Avicenna Journal of Phytomedicine, vol. 8, no. 1, pp. 73-84, 2018.

[117] V. Musolino, M. Gliozzi, S. Nucera et al., "The effect of bergamot polyphenolic fraction on lipid transfer protein system and vascular oxidative stress in a rat model of hyperlipidemia," Lipids in Health \& Disease, vol. 18, no. 1, 2019. 